\title{
o5. Türkçe ve İngilizcenin yabancı dil olarak öğretimine yönelik yüksek lisans programlarının karşılaştırmalı incelenmesi
}

\section{Gülnur AYDIN 1}

Elif İLHAN2

\begin{abstract}
APA: Aydın, G.; İlhan, E. (2021). Türkçe ve İngilizcenin yabancı dil olarak öğretimine yönelik yüksek lisans programlarının karşılaștırmalı incelenmesi. RumeliDE Dil ve Edebiyat Araştırmaları Dergisi, (23), 65-86. DOI: 10.29000/rumelide.948293.
\end{abstract}

\section{$\ddot{\mathbf{O} z}$}

Türkçe, dünyada yabancı dil olarak en çok öğrenilen/öğretilen dillerden biridir. Talebin artması öğretici ve onları yetiştirecek akademisyen gereksinimini de artırmaktadır. Bu nedenle yabancılara Türkçe öğretimi lisansüstü programlarının açılması kadar bunlara profesyonel bir kimlik kazandırılması da oldukça önemlidir. Profesyonel bir lisansüstü program kimliği oluşturmak için ise dünyada bu anlamda bilimsel birikimi güçlü olan benzer programları incelemek, benzerlik ve farklılıkları belirlemek gerekmektedir. Yabancılara İngilizce öğretimi yüksek lisans programları (MA-TESOL) bu bağlamda incelenmesi gereken programlar arasında yer almaktadır. Bu araştırmanın amacı, Türkiye'deki yabancılara Türkçe öğretimi ile İngiltere'deki yabancılara İngilizce öğretimi yüksek lisans programlarında yer alan derslerin karşılaştırmalı incelenmesidir. Karşılaştırmalı tarama modelinde tasarlanan bu nitel araştırmada, İngiltere ve Türkiye'den ölçüt örneklemeye uygun olarak belirlenen toplam 20 üniversitenin yüksek lisans programlarına ait program kılavuzları, ders katalogları, Avrupa Kredi Transfer Sistemi formları doküman incelemesi yöntemi ile incelenmiştir. Araştırmada, hem yabancılara Türkçe öğretimi hem de yabancılara İngilizce öğretimi yüksek lisans programlarında zorunlu ve seçmeli derslere ilişkin genel bir çerçeve sunulmuştur. Buna göre yüksek lisans programlarında bulunan dersler; araştırma, kuram, pedagoji, sosyoloji ve psikoloji olmak üzere beş ana tema ile bunlara bağlı pek çok alt temada toplanmıştır. Yüksek lisans programlarının ağırlıklı olarak ilk üç tema üzerine yapılandırıldığı belirlenmiştir. Araştırma sonuçlarından hareketle yabancılara Türkçe öğretimi yüksek lisans programlarının kuram teması altında dil bilimi ve dil edinimi; pedagoji teması altında öğretim yöntem ve teknikleri, ölçme-değerlendirme ve program geliştirme alt temalarına ilişkin seçmeli/zorunlu derslerin sayısının artırılması önerilebilir.

Anahtar kelimeler: Yabancılara Türkçe öğretimi, yüksek lisans programı, yabancılara İngilizce öğretimi

\section{A comparative analysis of master's degree programs on teaching Turkish and English to speakers of other languages}

\author{
Abstract \\ Turkish is one of the most widely learned/taught languages in the world as a foreign language. The \\ increase in demand also increases the need for instructors and academicians to train them. For this \\ Doç. Dr., Ankara Hacı Bayram Veli Üniversitesi, Lisansüstü Eğitim Enstitüsü, Yabancılara Türkçe Öğretimi ABD \\ (Ankara, Türkiye), gulnur.aydin@hbv.edu.tr, ORCID ID: o0oo-00o3-0490-9580 [Araştırma makalesi, Makale kayıt \\ tarihi: 17.04.2021-kabul tarihi: 20.06.2021; DOI: 10.29000/rumelide.948293] \\ $2 \quad$ Dr., Ankara Hacı Bayram Veli Üniversitesi, Rektörlük (Ankara, Türkiye), elif.ilhanoo@hbv.edu.tr, ORCID ID: oooo- \\ 0002-8536-1571 \\ RumeliDE Dil ve Edebiyat Araștırmaları Dergisi \\ Osmanağa Mahallesi, Mürver Ciçeği Sokak, No:14/8 \\ Kadıköy - ISTANBUL / TÜRKIYE 34714 \\ e-posta: editor@rumelide.com \\ tel: +90 $5057958124,+902167730616$ \\ Address \\ RumeliDE Journal of Language and Literature Studies \\ Osmanağa Mahallesi, Mürver Çiçeği Sokak, No:14/8 \\ Kadıköy - ISTANBUL / TURKEY 34714 \\ e-mail: editor@rumelide.com, \\ phone: +90 505 7958124, +90 2167730616
}


A comparative analysis of master's degree programs on teaching Turkish and English to speakers of other languages / G. Aydın; E.İlhan (pp. 65-86)

reason, it is very important to provide a professional identity to postgraduate programs in teaching Turkish to speakers of other languages as well as founding them. To establish a professional graduate program standard, it is necessary to examine similar programs with strong scientific knowledge in the world in this sense and to take steps by identifying similarities and differences. Master's degree programs in teaching English to speakers of other languages (MA-TESOL) are among the programs to be examined in this context. The study aims to examine the courses in the graduate programs, namely teaching Turkish to speakers of other languages in Turkey and teaching English to speakers of other languages in England. In this qualitative research designed based on a comparative survey model, program guides, course catalogs, European Credit Transfer System forms of a total of twenty master's degree programs in the UK and Turkey determined via criterionbased sampling method were analyzed using document analysis technique. A general framework regarding the compulsory and elective courses in both master's degree programs is presented in the study. Accordingly, the courses in graduate programs were gathered under five main themes, namely research, theory, pedagogy, sociology and psychology, and many sub-themes. It has been determined that master's degree programs are mainly structured on the first three themes. Based on the results, it may be suggested to increase the number of elective/compulsory courses of the master's degree programs on teaching Turkish to speakers of other languages, related to the subthemes namely linguistics and language acquisition under the theory theme; the sub-themes namely teaching methods and techniques, curriculum development and measurement-evaluation under the pedagogy theme.

Keywords: Teaching Turkish to speakers of other languages, master's degree program, teaching English to speakers of other languages

\section{Giriş}

Günümüz dünyası bireyi temel bir değer olarak gören, dolayısıyla ona ait dile ve kültüre de değer yükleyen; böylelikle kültürlerarası iletişim ve etkileşimin önem kazandı̆̆ 1 bir yöne evrilmiştir. Bu durum çok dilli ve çok kültürlü toplumların inşaasını hızlandırmış, bunun bir getirisi olarak da yabancı dil eğitimi gün geçtikçe daha da ilgi görmeye başlamış, tüm eğitim kademelerinde farklı ortam ve koşullara uyum sağlayabilecek, dünya algısı geniş bireyler yetiştirmek öncelenmiştir. Dil merkezli sosyal, kültürel, akademik ve mesleki roller, ihtiyaç duyulan yetkinliklere göre yeniden biçimlendirilirken bu rollerin bireylere kazandırılmasında eğitim programları, üzerinde düşünülmesi gereken bir etken olarak karşımıza çıkmaktadır.

21. yüzyılda Türkçe bir dizi gerekçeyle yabancı dil olarak en çok öğrenilen/öğretilen dillerden biri olmuştur. Artan talebi karşılayacak öğretici ihtiyacı, onları yetiştirecek akademisyen ihtiyacını da artırmaktadır. Bununla birlikte Türkçenin yabancı dil olarak uluslararasılaştırılması için bilimsel sınırları aşması gerektiği de açıktır. Bu nedenle yabancılara Türkçe öğretimi lisansüstü programları büyük önem arz etmektedir. Bu programlar, alanda bilimsel bilgi üretebilecek bilim insanları yetiştirebilmek kadar bilimsel birikimi olan bir alanın oluşmasında ve Türkçenin dünyaya daha nitelikli biçimde yayılmasında da belirleyicidir (Özbay ve Bahar, 2016; Uçgun, 2013).

Her ne kadar tarihi yüzyllar öncesine dayandırılsa da yabancılara Türkçe öğretiminde bilimsel ve kurumsal bir nitelik kazanma gereksinimi 20. yüzyllın sonlarında yaşanan hızlı küreselleşme sonucunda hissedilmeye başlanmıştır (İşcan, 2014). Bu bilimsel ve kurumsal nitelik kazanma sürecinde atılan geç kalınmış önemli adımlardan biri özellikle eğitim fakültelerinin Türkçe eğitimi

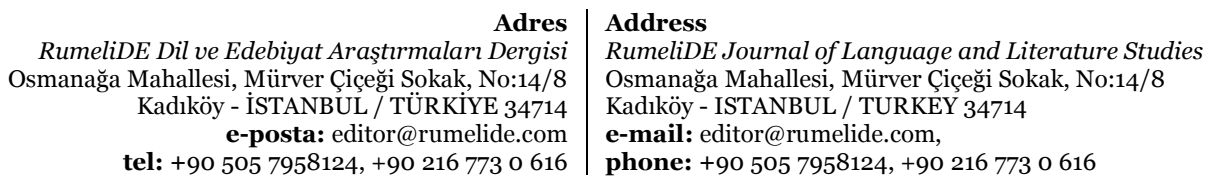


bölümleri bünyesinde açllan lisansüstü programlardır. YÖK verilerine göre3 Türkiye’de halihazırda yaklaşık 80 Türkçe Eğitimi lisans programı bulunmaktaysa da Türkçe eğitiminin bir alt alanı olarak kabul edilen yabancılara Türkçe öğretimi ile ilgili lisansüstü programların sayısı oldukça azdır (Özbay ve Bahar, 2016; Uçgun, 2013). 2021 yll itibarıla onyedi üniversitede yabancllara Türkçe öğretimi yüksek lisans (tezli), iki üniversitede doktora; bunun yanında beş üniversitede Yurtdışındaki Türk Çocuklarına Türkçe Öğretimi yüksek lisans programı bulunmaktadır.

Özel bir alan olduğu vurgulanan (Büyükaslan, 2007; Güzel, 2010; Yağmur, 2009) yabancılara Türkçe öğretiminin geciken kurumsallaşması niteliksel ve niceliksel sınırlılıkları da beraberinde getirmektedir. Başta Türkçe eğitimi alanı olmak üzere bugün yabancılara Türkçe öğretme sorumluluğunu üstlenen alanların lisans ve lisansüstü program içerikleri, yabancılara Türkçe öğretmek gibi özel bir alana öğretici yetiştirmek için yeterli değildir (Candaş-Karababa, 2009). "Bu alanda hem kuramsal hem de uygulamaya dayalı birikime sahip öğretim elemanları, ders kitapları, yardımcı ders materyalleri, ders programları ve genel olarak yabancılara Türkçeyi öğretme deneyimi konularında hazırlıksız pek çok üniversite, bu sınırlılıkları giderecek kadroları oluşturmaya çalışırken diğer taraftan da bu alanda uzun süredir faaliyet yürüten kurumların deneyimlerine başvurmaktadır" (Durmuş, 2013, s. 110). Bu bakımdan dünyada en yaygın kullanılan dillerden biri olan İngilizcenin yabancılara öğretimi (Teaching English to Speakers of Other Languages =TESOL) ile ilgili birikimden yararlanmak, olumlu ve olumsuz deneyimleri değerlendirmek faydalı olabilir. Eğitim programlarının, eğitimi yapılandırmadaki rolü ve eğitimin niteliğinin programla ilgisi dikkate alındığında henüz bir standardı olmayan yabancılara Türkçe öğretimi (YTÖ) yüksek lisans programları ile yabancılara İngilizce öğretimi (Yİ̈)4 yüksek lisans programlarını karşılaştırarak incelemek; mevcut durumun tespitinde ve içerik/süreç planlamada katkı sağlayabilir. YTÖ yüksek lisans programları ile Yi̇Ö yüksek lisans programlarının deneyimlerini bütünleşik olarak değerlendirmenin YTÖ yüksek lisans programlarına beklenen bilimsel ve akademik kimliği kazandırmada faydalı olacağı düşünülmektedir.

Yabancılara İngilizce öğretimi (YİÖ) yüksek lisans programları; ekonomik, teknolojik, siyasi gelişmelerin etkisiyle İngilizcenin dünya genelinde yaygınlaşmasına paralel olarak yaklaşık yüz yıldır özellikle İngiltere ve Amerika Birleşik Devletlerindeki üniversiteler başta olmak üzere pek çok ülkede üniversiteler tarafından sunulmaktadır. İngiltere'de elliden fazla üniversitede YïÖ yüksek lisans programı bulunmaktadır ( $\mathrm{Wu}$, Qiu, Hutagalung ve McNeill-Keay, 2020). YİÖ yüksek lisans programlarının genel amacı; İngilizce öğretimine ilişkin kuramsal ve uygulamalı bilgilerin öğrencilere kazandırılmasıdır. Bu programı uzun yıllardır başarıyla uygulayan Mancaster Universitesi programın genel amaçlarını; öğrencilere ilgili alanyazındaki kuram, araştırma ve tartışmalar hakkında farkındalık kazandırmak; ihtiyaç analizi, öğrenme- öğretme materyallerinin geliştirilmesi/ uygulanması/ tasarlanması gibi mesleki beceriler kazandırmak (Mancaster Üniversitesi, 2021); York Universitesi ise öğrencilerin dil öğrenme ve öğretmeye ilişkin güncel kaynakları/yeni eğilimleri anlamasını, bunların öğrenme ortamlarında nasıl uygulandığının farkına varmasını ve ilgili araştırmalar yapmalarını sağlamak olarak sıralamaktadır (York Üniversisitesi, 2021).

İlgili alanyazın tarandığında doğrudan YTÖ yüksek lisans programlarına ilişkin herhangi bir araştırmaya rastlanmamıştır. Aytan, Uzun ve Günaydın (2020) hayat boyu öğrenme yabancılara Türkçe öğretim kurs programlarının çeşitli değişkenler açısından değerlendirmesini yapmışlardır.

https://yokatlas.yok.gov.tr/lisans-bolum.php?b=10215/18 Mart 2021

"Teaching English to Speakers of Other Languages" yüksek lisans programının Türkçe karşıllğı olarak araştırma kapsamındaki Yabancılara Türkçe Öğretimi programlarıyla karşılaştırmada anlaşllırlığı sağlamak için "Yabancılara İngilizce Öğretimi” adının kullanılması tercih edilmiştir.

Adres | Address

RumeliDE Dil ve Edebiyat Araşttrmaları Dergisi $\quad$ RumeliDE Journal of Language and Literature Studies Osmanağa Mahallesi, Mürver Çiçeği Sokak, No:14/8 Osmanağa Mahallesi, Mürver Çiçeği Sokak, No:14/8 Kadıköy - İSTANBUL / TÜRKIYE 34714 Kadıköy - ISTANBUL / TURKEY 34714 e-posta: editor@rumelide.com tel: +90 $5057958124,+90216773$ o 616 phone: +90 505 7958124, +90 216773 o 616 
A comparative analysis of master's degree programs on teaching Turkish and English to speakers of other languages / G. Aydın; E.̇̇lhan (pp. 65-86)

Demiral ve Kökçü (2018) yabancllara Türkçe öğretimi sertifika programına katılan öğrencilerin sertifika programları hakkındaki görüşleri; Kurt (2020) Yabancı dil olarak Türkçe öğretimi programına ilişkin kursiyer görüşlerinin karşılaştırılmalı analizi; Çetin (2020) ise yabancılara Türkçe öğretimi sertifika programlarında görülen eksiklikler ve çözüm önerileri üzerine çalışmışlardır. Bunun yanında Balcı ve Melanlığlu'nun (2020) çalışmasında Türkiye Maarif Vakfının örgün eğitim kurumları için tasarladığı "Türkçenin yabancı dil olarak öğretimi programı" içerik bakımından değerlendirilmiş ve benzer programlarla karşlaştırılmıştır. Bu araştırmaların hiçbiri doğrudan lisansüstü programlar özelinde yapılmamıştır. Bu nedenle bu araştırma, alanyazındaki gereksinimi karşlayacak niteliktedir.

YİÖ yüksek lisans programlarıyla ilgili alanyazını incelendiğinde pek çok araştırmanın yapıldığı görülmektedir (Hasrati \& Tavakoli, 2015; Ilieva, Li \& Li, 2015; Ilieva \& Ravindran, 2018; Murphy, 1997; Di Pietro, Lantolf \& Labarca, 1983; Ramanathan, Davies \& Schleppegrell, 2012; Vasquez \& Sharpless, 2009; Wu, Qiu, Hutagalung ve McNeill-Keay, 2020 vb.). Bu araştırmalarla ve artık standart haline gelen uygulamalarla YíÖ yüksek lisans programlarının uluslararası bilimsel kimlik kazandığı söylenebilir. YTÖ yüksek lisans programları ile ilgili de uluslararası bilimsel kimlik kazandıracak nitelikte çalışmalara gereksinim vardır.

Bu araştırmanın genel amacı, Türkiye'deki yabancılara Türkçe öğretimi ile İngiltere'deki yabancılara İngilizce öğretimi yüksek lisans programlarında yer alan derslerin karşılaştırmalı incelenmesidir. Bu amaçla, yabancılara Türkçe öğretimi ile yabancılara İngilizce öğretimi yüksek lisans programlarında yer alan zorunlu/seçmeli derslerin niceliksel ve tematik dağılımı incelenmiş ve karşılaştırılmıştır.

\section{Yöntem}

\subsection{Araştırma modeli/ deseni}

Bu araştırmada YTÖ ve YïÖ yüksek lisans programları karşılaştırmalı bir biçimde incelendiğinden karşılaştırmalı tarama modeli benimsenmiştir (Karasar, 2016, s. 109). Bu doğrultuda Türkiye ve İngiltere'den onar farklı üniversitenin yabancılara dil öğretimi yüksek lisans programları belli değişkenler açısından detaylı bir şekilde betimlenmiş, daha sonra ise bu betimlemeler karşılaştırılarak benzerlik ve farklılıklar ortaya konmuştur (Karasar, 2016, s. 117). Betimleme/karşllaştırma sürecinde doküman incelemesi yöntemi kullanıldığından araştırma nitel araştırma özelliği taşımaktadır.

\section{2. Çalışma grubu ve veri kaynakları}

Araştırmanın çalışma grubunu, YTÖ yüksek lisans programları için Türkiye'den 10, YïÖ yüksek lisans programları için İngiltere'den 10 olmak üzere toplam 20 üniversite oluşturmaktadır. Bu üniversiteler; amaçlı örnekleme yöntemlerinden ölçüt örnekleme ile belirlenmiştir. Ölçütler; incelenecek üniversitelerin tezli yüksek lisans programlarının hâlihazırda eğitim veriyor olması, programa ait ders bilgi paketlerinin resmi web sitelerinde ulaşılabilir olması; İngiltere'de lisansüstü eğitim programı sayısının çok fazla olmasından dolayı ilk iki ölçüte ek olarak incelenecek üniversitelerin, dünya genelindeki üniversite başarı sıralamasında ilk 150'de yer alması olarak belirlenmiştir5. Amaçlı örneklemede, araştırmanın amacına göre en geçerli ve güvenilir bilgiyi sağlayacak kurum, nesne veya kişiler araştırmacı tarafından seçilir (O'Leary, 2013). Buna göre belirlenen üniversiteler ve ilgili üniversitelerdeki programlar Tablo 1'de görülmektedir.

The Times Higher Education World University Rankings 2020 temel alınmıștır.

Adres $\mid$ Address

RumeliDE Dil ve Edebiyat Araştırmaları Dergisi $\quad$ RumeliDE Journal of Language and Literature Studies Osmanağa Mahallesi, Mürver Çiçeği Sokak, No:14/8 Osmanağa Mahallesi, Mürver Çiçeği Sokak, No:14/8 Kadıköy - İSTANBUL / TÜRKIYE 34714 Kadıköy - ISTANBUL / TURKEY 34714 e-posta: editor@rumelide.com

e-mail: editor@rumelide.com

tel: +90 505 7958124, +90 2167730616 phone: +90 505 7958124, +90 2167730616 
Tablo 1. Araştırmanın çalışma grubunu oluşturan üniversiteler ve yüksek lisans programları

\begin{tabular}{|c|c|c|c|c|c|}
\hline \multicolumn{3}{|c|}{ TÜRKIYYE } & \multicolumn{3}{|c|}{ İNGİLTERE } \\
\hline & Üniversite & YL Programi* & & Üniversite & YL Programi** \\
\hline $\mathbf{1}$ & $\begin{array}{l}\text { Ankara Hacı } \\
\text { Bayram Veli }\end{array}$ & $\begin{array}{l}\text { Yabancılara Türkçe } \\
\text { Öğretimi }\end{array}$ & $\mathbf{1}$ & Andrews & $\begin{array}{l}\text { Yabancilara İngilizce } \\
\text { Öğretimi }\end{array}$ \\
\hline 2 & $\begin{array}{l}\text { Bolu Abant İzzet } \\
\text { Baysal }\end{array}$ & $\begin{array}{l}\text { Yabancı Dil Olarak } \\
\text { Türkçe Öğretimi }\end{array}$ & 2 & Birmighman & $\begin{array}{l}\text { Yabancilara İngilizce } \\
\text { Öğretimi }\end{array}$ \\
\hline 3 & Bursa Uludă̆ & $\begin{array}{l}\text { Yabancı Dil Olarak } \\
\text { Türkçe Öğretimi }\end{array}$ & 3 & Glasgow & $\begin{array}{l}\text { Yabancilara İngilizce } \\
\text { Öğretimi }\end{array}$ \\
\hline 4 & $\begin{array}{l}\text { Çanakkale } 18 \\
\text { Mart }\end{array}$ & $\begin{array}{l}\text { Yabancı Dil Olarak } \\
\text { Türkçenin Öğretimi }\end{array}$ & 4 & $\begin{array}{l}\text { King's College of } \\
\text { London (KCL) }\end{array}$ & $\begin{array}{l}\text { Yabanclara İngilizce } \\
\text { Öğretimi }\end{array}$ \\
\hline 5 & Hacettepe & $\begin{array}{l}\text { Yabancı Dil Olarak } \\
\text { Türkçe Öğretimi }\end{array}$ & 5 & Lancaster & $\begin{array}{l}\text { Yabancılara İngilizce } \\
\text { Öğretimi }\end{array}$ \\
\hline 6 & Istanbul & $\begin{array}{l}\text { Yabancı Dil Olarak } \\
\text { Türkçe Öğretimi }\end{array}$ & 6 & Mancaster & $\begin{array}{l}\text { Yabancilara İngilizce } \\
\text { Öğretimi }\end{array}$ \\
\hline 7 & Kocaeli & $\begin{array}{l}\text { Yabancılara Türkçe } \\
\text { Öğretimi }\end{array}$ & 7 & Nottingman & $\begin{array}{l}\text { Yabancilara İngilizce } \\
\text { Öğretimi }\end{array}$ \\
\hline 8 & $\begin{array}{l}\text { Nevşehir Hacı } \\
\text { Bektaş Veli }\end{array}$ & $\begin{array}{l}\text { Yabancılara Türkçe } \\
\text { Öğretimi }\end{array}$ & 8 & $\begin{array}{l}\text { University } \\
\text { College London } \\
\text { (UCL) }\end{array}$ & $\begin{array}{l}\text { Yabancllara İngilizce } \\
\text { Öğretimi }\end{array}$ \\
\hline 9 & Sakarya & $\begin{array}{l}\text { Yabancılar İçin Türkçe } \\
\text { Öğretimi }\end{array}$ & 9 & Warvick & $\begin{array}{l}\text { Yabancllara İngilizce } \\
\text { Öğretimi }\end{array}$ \\
\hline 10 & 9 Eylül & $\begin{array}{l}\text { Yabancı Dil Olarak } \\
\text { Türkçe Öğretimi }\end{array}$ & 10 & York & $\begin{array}{l}\text { Yabancilara İngilizce } \\
\text { Öğretimi }\end{array}$ \\
\hline \multicolumn{6}{|c|}{$\begin{array}{l}\text { *Türkiye’deki yülksek lisans programları arasındaki adlandırmalar açısından görülen farklılıklar dikkate alınara } \\
\text { kavram karışıklığına neden olmamak için bu araştırmada "Yabancırara Türkçe Öğretimi” adının kullanılması } \\
\text { tercih edilmiştir. } \\
\text { ** “Teaching English to Speakers of Other Languages” yüksek lisans programının Türkçe karşılığı olarak }\end{array}$} \\
\hline
\end{tabular}

Araştırma kapsamında yer alan Türkiye ve İngilitere'deki toplam 20 üniversitenin resmi internet sayfalarında yayınlanan bilgiler, program kılavuzları, ders katalogları, Avrupa Kredi Transfer Sistemi (AKTS-ECTS) formları, veri kaynakları olarak incelenmiştir. Veri kaynaklarının, güncellik, geçerlik ve güvenirlik durumu göz önünde bulundurulmuştur.

\subsection{Verilerin toplanması ve analizi}

\section{Veri toplama aracının geliştirilmesi}

Araştırmada veriler, doküman incelemesi formu aracılığıyla toplanmıştır. YTÖ-YiÖ Yüksek Lisans Programları İnceleme Formu olarak adlandırılan bu form, iki satır ve altı sütundan oluşmaktadır. 
A comparative analysis of master's degree programs on teaching Turkish and English to speakers of other languages / G. Aydın; E.İlhan (pp. 65-86)

Tablo 2. YTÖ-YİÖ Yüksek Lisans Programları İnceleme Formu

\begin{tabular}{|c|c|c|c|c|c|}
\hline Üniversite & Program Adı & $\begin{array}{l}\text { Zorunlu } \\
\text { Dersler }\end{array}$ & Seçmeli Dersler & $\begin{array}{l}\text { Toplam } \\
\text { Ders Sayısı }\end{array}$ & Notlar \\
\hline
\end{tabular}

Araştırmada kullanılan doküman inceleme formunun kapsam, yapı ve görünüş geçerliliğinin sağlanması amacıyla nitel araştırma ve yükseköğretimde eğitim programları alanından çalışmaları olan iki program geliştirme uzmanından ve yabancı dil eğitimi alanında çalışmaları olan bir uzmandan görüş alınmıştır. Alınan uzman görüşlerine dayalı olarak doküman inceleme formunda dersler zorunlu ve seçmeli olarak ayrılmış, form, biçimsel olarak tekrar düzenlenmiştir.

\section{Veri toplama süreci ve analizi}

$\mathrm{Bu}$ araştırmanın verilerine; Kasım,2020 ile Ocak,2021 tarih aralığında ulaşılmıştır. Kapsama alınan üniversitelerin/ programların resmi siteleri üzerinden ulaşlan veriler, YTÖ-YIÖ Yüksek Lisans Programları İnceleme Formu aracılığıyla sınıflandırılmış ve incelenmiştir. Türkiye'deki YTÖ yüksek lisans programları ve programlardaki 205 ders ile İngiltere'deki YïÖ yüksek lisans programları ve programlardaki 119 derse ilişkin veriler incelenmiştir. Her iki programda da birinci ve ikinci yarıyıl dersleri inceleme kapsamına alınmıştır. Her bir yüksek lisans programı için ayrı ayrı doldurulan doküman inceleme formları dosyalanarak analize hazır hale getirilmiştir. Daha sonra oluşturulmuş olan tablolardaki veriler; Mart, 2021 tarihinde tekrar incelenmiş, güncelliği kontrol edilmiştir.

Araştırma kapsamında ulaşılan verilerin analizinin yapılabilmesi için doküman incelemesi yöntemi kullanılmıştır. Doküman incelemesi yöntemi, araştırılması hedeflenen olgu veya olgular hakkında bilgi içeren materyallerin analizini kapsar (Yıldırım \& Şimşek, 2013, s.217). Bu kapsamda erişilen dokümanlardaki programlarda yer alan derslere ilişkin veriler sistematik bir yöntemle (Fraenkel, Wallen, \& Hyun, 1993) aşağıdaki aşamalara göre analiz edilmiştir (Forster'den aktaran Yıldırım \& Şimşek, 2013, s.223-231):

1. Dokümanlara Ulaşma: İncelenen yüksek lisans programlarının bağlı olduğu üniversitelerin resmi internet sayfalarında yayınlanan bilgiler, program kllavuzları, ders katalogları, Avrupa Kredi Transfer Sistemi (AKTS-ECTS) formlarına ulaşılmıştır.

2. Orïinalliğini Kontrol Etme: Araştırmada birincil veri kaynakları kullanılmış, dokümanlardaki verilerin güncelliği kontrol edilmiştir.

3. Dokümanlar Anlama: Dokümanlardaki bilgiler ilgili alanyazın kapsamında incelenerek anlamlandırılmıştır.

4. Veriyi Analiz Etme: Ulaşılan dokümanlardaki ders sayıları nicel, derslere ilişkin bilgiler ise tematik olarak analiz edilmiştir. Bu aşamanın analize konu olan veriden örneklem seçme alt aşamasında; dersler ve bunlarla ilişkili bilgiler analize dâhil edilmiştir. Temalar geliștirme alt aşamasında; derslere ilişskin bilgiler irdelenerek, araştırmacılar tarafindan temalar/alt temalar belirlenmiştir. Analiz birimini saptama aşamasında ders adlarındaki/genel tanıtımlarındaki sözcük, cümle ve içerik, analiz birimi olarak belirlenmiştir. Sayısallaştrrma alt aşamasında ise sayısal değerler ve yüzde dağıllımları belirlenmiştir.

5. Veriyi Kullanma: Yapılan analiz sonuçları tablo ve grafiklere dönüştürülerek açıklanmış ve tartışılmıştır.

Araştırmanın veri analizi sürecinde iç güvenirliği (tutarlılığı) artırmak için araştırmacılardan kaynaklanması olası yanlılığın ortadan kaldırılmasına yönelik önlemler alınmıştır (Merriam, 2013). Bu amaçla öncelikle toplanan verilerin \%20'si için ayrı ayrı temalar oluşturulmuş, bu temalar araştırmacıların bir araya geldiği eleştirel inceleme toplantısında değerlendirilerek bir analiz tablosu

\begin{tabular}{|c|c|}
\hline & \\
\hline eliDE Dil ve Edebiyat Araştırmaları De & E Journal of Language and Literature Studies \\
\hline 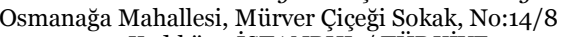 & Mahallesi, Mürver Çiçeği Sokak, No:14/8 \\
\hline Kadıköy $-\mathrm{I}$ & ISTANBUL / TURKEY 34714 \\
\hline $\begin{array}{r}\text { e-posta: editor } \\
\text { tel: }+905057958124,+9\end{array}$ & $\begin{array}{l}\text { editor@rumelide.com, } \\
\text { +90 505 7958124, +90 } 2167730616\end{array}$ \\
\hline
\end{tabular}


hazırlanmıştır. Bu toplantıda alınan kararlar ve oluşturulan tablo kullanılarak verilerin geriye kalan kısmı yine iki araştırmacı tarafından ayrı ayrı analiz edilmiştir. Daha sonra araştırmacılar arası uyum geçerliliğini sağlamak için kodlayıcılar arası güvenirlik [uzlaşılan temalar/(uzlaşlan + uzlaşılmayan temalar)]x10o formülü (Miles \& Huberman, 1994, s.64) ile hesaplanmış ve \%88 olarak belirlenmiştir $([53 /(53+7)] \times 100=88)$. Miles ve Huberman'a (1994) göre kodlayıcılar arası güvenirlik \%80'den büyük ve mümkün olduğunca \%9o’a yakın olmalıdır. Bu sonuç, kodlamaların tutarlılığını sağlamada yeterlidir. Bununla birlikte oluşturulan temaların doğru ve etkili sunumu için veri toplama araçlarının hazırlanma sürecinde görüşleri alınan uzmanların görüş ve önerilerine tekrar başvurulmuştur. Araştırmanın ham verileri (her bir YTÖ-YİÖ Yüksek Lisans Programları İnceleme Formu), başka araştırmacıların denetimine sunulabilecek şekilde saklanmıştır

\section{Bulgular ve yorum}

\subsection{YTÖ ve Yiö yüksek lisans programlarındaki zorunlu ve seçmeli ders sayıları}

Araştırma kapsamında incelenen YTÖ yüksek lisans programlarına ait zorunlu ve seçmeli ders sayıları Tablo 3’te sunulmuştur.

Tablo 3. Yabancılara Türkçe Öğretimi Yüksek Lisans Programlarındaki Dersler***

\begin{tabular}{lllll}
\hline \multirow{2}{*}{ Üniversiteler } & \multicolumn{4}{c}{ Ders Sayıs** } \\
\cline { 2 - 5 } & Zorunlu & Sunulan Seçmeli & Seçilen Seçmeli & Toplam \\
\hline Ankara Hacı Bayram Veli & 2 & 21 & 6 & 8 \\
\hline Bolu Abant İzzet Baysal & 3 & 12 & 3 & 6 \\
\hline Bursa Uludağ & 2 & 27 & 7 & 9 \\
\hline Çanakkale 18 Mart & 3 & 29 & 5 & 10 \\
\hline Hacettepe & 4 & 28 & 6 \\
\hline Istanbul & 2 & 8 & 6 & 9 \\
\hline Kocaeli & 3 & 8 & 6 & 10 \\
\hline Nevşehir Hacı Bektaş Veli & 2 & 19 & 8 & 10 \\
\hline Sakarya & 5 & 11 & 5 & 8 \\
\hline 9 Eylül & 3 & 15 & $5^{*}$ & 8 \\
\hline
\end{tabular}

***Tabloda yer alan bilgiler yüksek lisans programlarının birinci ve ikinci ders dönemine ilişkindir.

**Ders sayılarının açıç̧a belirtilmediği programlarda mezuniyet için gerekli toplam ve her bir dersin AKTS yükleri dikkate alınarak ders sayısı belirlenmiştir.

${ }^{*}$ Seçilen dersin AKTS kredisine göre farklılık gösterebilmektedir.

İncelenen yabancılara Türkçe öğretimi tezli yüksek lisans programlarında öğrencilerin tezli yüksek lisans programlarının birinci ve ikinci döneminde almak zorunda oldukları toplam ders sayıları altı ila on arasında değişiklik göstermektedir. Türkiye'de yüksek lisans programlarında genel olarak toplamda öğrencilere sekiz ders verilmektedir. Yabancılara Türkçe öğretimi programının disiplinlerarası olma özelliği dikkate alındığında bu nispeten fazla olan ders sayılarına gereksinim olduğu düşünülebilir. Çünkü farklı disiplinlerden gelen öğrencilerin tez dönemine geçmeden önce yabancılara Türkçe öğretimi alanına ilişkin kuramsal ve uygulamalı bilgi/beceriler ile temel bilimsel araştırma bilgi/becerilerini kazanmaları beklenmektedir. 
A comparative analysis of master's degree programs on teaching Turkish and English to speakers of other languages / G. Aydın; E.İlhan (pp. 65-86)

İncelenen programlarda zorunlu derslerin sayısı en az iki, en fazla beştir. YÖK tarafından zorunlu tutulan "araştırma teknikleri ve yayın etiği” ile ilgili derslerin farklı adlandırmalarının yanı sıra genelde başka zorunlu dersler de yer almaktadır. İncelenen programlarda öğrencilere sunulan seçmeli ders sayıları da en az sekiz ve en fazla yirmi dokuz olmak üzere geniş bir ölçekte değişiklik göstermektedir. Öğrencilerin seçmek zorunda oldukları ders sayısı ile sunulan ders sayısının oranları dikkate alındığında da yine programlar arasında farklılıklar olduğu görülmektedir. Örneğin; İstanbul ve Kocaeli üniversitelerindeki YTÖ yüksek lisans programlarına devam eden öğrencilerin istediği dersi seçme özgürlüğü daha sınırlı iken Hacettepe, Çanakkale, Uludağ üniversitelerinde bunun daha geniş olduğu anlaşılmaktadır. Öğrencilerin daha geniş bir ders listesinden ders seçme hakkına sahip olmaları, onların kendi ilgi/istek/ihtiyaçları doğrultusunda belirleyecekleri alt uzmanlık alanlarında akademik/mesleki kariyerlerine devam etmeleri açısından çok önemlidir.

Araştırma kapsamında incelenen YİÖ yüksek lisans programlarına ait zorunlu ve seçmeli ders sayıları Tablo 4'te sunulmuştur.

Tablo 4. Yabancılara İngilizce Öğretimi Yüksek Lisans Programlarındaki Dersler

\begin{tabular}{|c|c|c|c|c|}
\hline \multirow{2}{*}{ Üniversiteler } & \multicolumn{3}{|c|}{ Ders Sayısı } & \multirow[b]{2}{*}{ Toplam } \\
\hline & Zorunlu & Sunulan Seçmeli & Seçilen Seçmeli & \\
\hline Andrews & 5 & 5 & 3 & 8 \\
\hline Birmighman & 4 & 12 & 2 & 6 \\
\hline Glasgow & 4 & 9 & 2 & 6 \\
\hline KCL & 3 & 12 & 2 & 5 \\
\hline Lancaster & 5 & o & o & 5 \\
\hline Mancaster & 3 & 10 & 1 & 4 \\
\hline Nottingman & 2 & 5 & 2 & 4 \\
\hline UCL & 1 & 10 & 3 & 4 \\
\hline Warvick & 6 & 8 & 2 ya da $3^{*}$ & 8 ya da $9^{*}$ \\
\hline York & 5 & 10 & 1 & 6 \\
\hline
\end{tabular}

*ílgili programda, öğrencilere iki ya da üç ders seçme şansı tanınmıştır.

İncelenen yabancılara İngilizce öğretimi tezli yüksek lisans programlarında öğrencilerin almak zorunda oldukları ders sayıları dört ila dokuz arasında değişiklik göstermektedir. İncelenen programlarda zorunlu derslerin sayısı en az bir, en fazla altı olacak şekilde değişiklik göstermektedir. YİÖ yüksek lisans programlarında sunulan zorunlu dersler tamamen ilgili yüksek lisans programında görev yapan öğretim üyelerinin kararı ile eğitim programlarına dâhil edilmektedir. YTÖ yüksek lisans programlarında olduğu gibi herhangi bir üst denetleme kurulu tarafından programlara müdahale edilmemektedir. İncelenen programlardan Lancaster Üniversitesi YïÖ yüksek lisans programında öğrencilere seçmeli ders sunulmaması dikkat çekicidir. Bunun nedeni programın tamamen uzaktan eğitim yoluyla öğrencilere sunulması olabilir. Bunun haricindeki programlarda sunulan seçmeli ders sayıları da en az beş ve en fazla on iki dersdür. Öğrencilerin seçmek zorunda oldukları ders sayısı ile sunulan ders derslerinin oranları dikkate alındığında da yine programlar arasında farklılıklar olduğu görülmektedir. Örneğin; Birmighman, Mancaster ve York üniversitelerinde YïÖ yüksek lisans programlarına devam eden öğrencilerin daha geniş bir yelpazeden ders tercihinde bulunabildiği görülmektedir. Öte yandan seçmeli derslerin sayısı dikkate alındığında ise öğrencilerin ders seçme

Adres Address

RumeliDE Dil ve Edebiyat Araştırmalar Dergisi $\quad$ RumeliDE Journal of Language and Literature Studies Osmanağa Mahallesi, Mürver Çiçeği Sokak, No:14/8 Osmanağa Mahallesi, Mürver Çiçeği Sokak, No:14/8

Kadıköy - ISTANBUL / TÜRKIYE 34714 Kadıköy - ISTANBUL / TURKEY 34714 e-posta: editor@rumelide.com e-mail: editor@rumelide.com,

tel: +90 505 7958124, +90 2167730616 phone: +90 505 7958124, +90 2167730616 
özgürlüğünün incelenen programların çoğunda sınırlı olduğu düşünülebilir. Örneğin York ve Mancaster üniversitelerinde öğrenciler yalnızca bir ders seçme hakkına sahiptir. Öğrencilerin kendi ilgi/istek/ihtiyaçları doğrultusunda belirleyecekleri ders sayısının az olması onların akademik/mesleki kariyerlerinde alt uzmanlık alanları belirleme durumlarını olumsuz etkileyebilir.

\subsection{YTÖ ve YïÖ yüksek lisans programlarında yer alan zorunlu ve seçmeli derslerin tematik olarak incelenmesi}

Araştırma kapsamında on üniversitedeki YTÖ yüksek lisans programlarına ait toplam 205 ders incelenmiştir. Bu derslerin belirlenen temalara göre dağılımı ve zorunlu/ seçmeli ders sayıları Tablo 5 ’te sunulmuştur.

Tablo 5. Yabancılara Türkçe Öğretimi Yüksek Lisans Programlarındaki Zorunlu ve Seçmeli Derslerin Temalara Göre Dağılımı

\begin{tabular}{|c|c|c|c|c|c|c|c|c|c|c|c|c|c|c|c|c|c|c|c|c|c|c|c|}
\hline \multicolumn{2}{|c|}{ ÜNIVERSİTELER } & \multicolumn{2}{|c|}{ 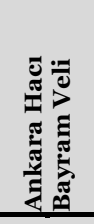 } & \multicolumn{2}{|c|}{ 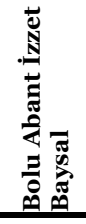 } & \multicolumn{2}{|c|}{ 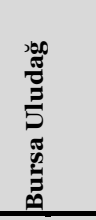 } & \multicolumn{2}{|c|}{ 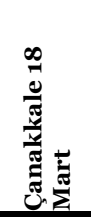 } & \multicolumn{2}{|c|}{ 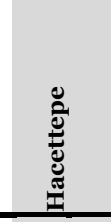 } & \multicolumn{2}{|c|}{ हే } & \multicolumn{2}{|c|}{ 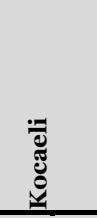 } & \multicolumn{2}{|c|}{ 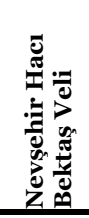 } & \multicolumn{2}{|c|}{ స్ㅐㅠ } & \multicolumn{2}{|c|}{$\begin{array}{l}\text { : } \\
\text { 空 } \\
a \\
\end{array}$} & \multicolumn{2}{|c|}{ हี } \\
\hline TEMALAR & $\begin{array}{l}\text { ALT } \\
\text { TEMALAR }\end{array}$ & $\mathbf{Z}$ & $\mathbf{S}$ & $\mathbf{Z}$ & $\mathbf{S}$ & $\mathbf{Z}$ & $\mathbf{S}$ & $\mathbf{Z}$ & $\mathbf{S}$ & $\mathbf{Z}$ & $\mathbf{S}$ & $\mathbf{Z}$ & $\mathbf{S}$ & $\mathbf{Z}$ & $\mathbf{S}$ & $\mathbf{Z}$ & $\mathbf{S}$ & $\mathbf{Z}$ & $\mathbf{S}$ & $\mathbf{Z}$ & $\mathbf{S}$ & $\mathbf{Z}$ & $\mathbf{S}$ \\
\hline \multirow[t]{2}{*}{ Araştırma } & $\begin{array}{l}\text { Bilimsel } \\
\text { araştırma }\end{array}$ & 2 & & 1 & & 2 & 1 & 3 & 1 & 2 & 2 & 2 & & 3 & & 2 & 1 & 1 & & 2 & & 20 & 5 \\
\hline & Toplam & & & & & & & & & & & & & & & & & & & & & 20 & 5 \\
\hline \multirow{7}{*}{ Kuram } & Dil bilimi & & 2 & & 1 & & 1 & & 2 & & 3 & & 1 & & 1 & & 2 & & 2 & 1 & 3 & 1 & 18 \\
\hline & Dil edinimi & & 1 & & 1 & & 1 & & 1 & & 1 & & 1 & & & & 1 & & 1 & & & & 8 \\
\hline & Söz varlığı & & 1 & & 1 & & 2 & & 1 & & & & 1 & & 1 & & & & & & 2 & & 6 \\
\hline & $\begin{array}{l}\text { Dilin gelişimi } \\
\text { ve yayılımı }\end{array}$ & & 1 & & & & & & & & 2 & & & & & & & & & & & & 3 \\
\hline & $\mathrm{AB}$ çerçeve & & 1 & & & & 1 & & & & 1 & & & & & & & & & & & & 3 \\
\hline & YTÖ tarihi & & & & 1 & & 1 & & & & & & & & & & & & & & & & 2 \\
\hline & Toplam & & & & & & & & & & & & & & & & & & & & & $\mathbf{1}$ & 40 \\
\hline \multirow{9}{*}{ Pedagoji } & $\begin{array}{l}\text { Öğretim } \\
\text { yöntem ve } \\
\text { teknikleri }\end{array}$ & & 4 & & 2 & & 10 & & 8 & 2 & 2 & & 1 & & 2 & & 3 & 2 & 4 & & 2 & 4 & 38 \\
\hline & $\begin{array}{l}\text { Dilbilgisi ve } \\
\text { öğretimi }\end{array}$ & & 1 & & 1 & & 2 & & 2 & & 3 & & 2 & & 2 & & 3 & & 1 & & 3 & & 20 \\
\hline & $\begin{array}{l}\text { Materyal } \\
\text { geliştirme/ } \\
\text { değerlendirme }\end{array}$ & & 2 & & 2 & & 5 & & 3 & & 2 & & & & 1 & & 2 & 2 & 1 & & 2 & 2 & 20 \\
\hline & $\begin{array}{l}\text { Dil } \\
\text { becerilerinin } \\
\text { öğretimi }\end{array}$ & & 2 & 2 & & & 2 & & 5 & & 2 & & 1 & & 2 & & 2 & & 1 & & 2 & 2 & 19 \\
\hline & $\begin{array}{l}\text { Öğretim } \\
\text { teknolojileri }\end{array}$ & & 1 & & & & 3 & & 2 & & 1 & & 1 & & & & 1 & & & & & & 9 \\
\hline & $\begin{array}{l}\text { Ölçme- } \\
\text { değerlendirme }\end{array}$ & & & & 1 & & 1 & & & & 1 & & & & & & 1 & & 1 & & & & 5 \\
\hline & $\begin{array}{l}\text { İki/çok dillilik } \\
\text { ve öğretimi }\end{array}$ & & 1 & & & & & & & & & & & & & & & & 2 & & & & 2 \\
\hline & $\begin{array}{l}\text { Gözlem- } \\
\text { uygulama }\end{array}$ & & & & & & & & 1 & & & & & & & & & & & & & & 1 \\
\hline & $\begin{array}{l}\text { Program } \\
\text { geliştirme }\end{array}$ & & & & & & & & & & 1 & & & & & & & & & & & & 1 \\
\hline & $\begin{array}{r}\text { RumeliDE } \\
\text { Osmanağa Ma } \\
\mathrm{K} \\
\text { tel }\end{array}$ & $\begin{array}{l}\text { il ve } \\
\text { alle } \\
\text { llkö }\end{array}$ & $\begin{array}{l}\text { Ede } \\
\text { i, M } \\
\text { - İS } \\
\text { e-p } \\
505\end{array}$ & $\begin{array}{l}y a t \\
\text { rver } \\
\text { ANI }\end{array}$ & e & So & $\begin{array}{l}\text { larn } \\
\text { ak, } \\
\text { KIYY } \\
\text { meli }\end{array}$ & $\begin{array}{l}\text { dre } \\
\text { ergis } \\
: 14 / \\
3471 \\
. c 01\end{array}$ & & $\begin{array}{l}\text { Add } \\
\text { Rum } \\
\text { Osm } \\
\text { Kadi } \\
\text { e-m } \\
\text { pho }\end{array}$ & ess & $\begin{array}{l}J o u \\
\text { Mal } \\
\text { STA } \\
\text { itor }\end{array}$ & $\begin{array}{l}\text { nal } \\
\text { alles } \\
\text { NBU } \\
\text { rur }\end{array}$ & $\begin{array}{l}\text { Cal } \\
\text { Mü } \\
\text { / T }\end{array}$ & & $\begin{array}{l}\text { e an } \\
\text { içeğ } \\
\mathrm{Y} 34\end{array}$ & $\begin{array}{l}\text { Sok } \\
14\end{array}$ & atu & $\begin{array}{l}e S t \\
14 /\end{array}$ & & & & \\
\hline
\end{tabular}




\begin{tabular}{|c|c|c|c|c|c|c|c|c|c|c|c|}
\hline & Sinıf yönetimi & & & & 1 & & & & & & 1 \\
\hline & Toplam & & & & & & & & & 8 & 116 \\
\hline \multirow[t]{4}{*}{ Sosyoloji } & Kültür & 1 & 1 & 3 & 3 & 1 & 2 & 1 & 2 & & 14 \\
\hline & İletişim & & & & 2 & & & & & & 2 \\
\hline & $\begin{array}{l}\text { Cinsiyet } \\
\text { eşitliği }\end{array}$ & & & & & & 1 & & & & 1 \\
\hline & Toplam & & & & & & & & & o & 17 \\
\hline \multirow[t]{3}{*}{ Psikoloji } & Motivasyon & & & & & 1 & 1 & & & & 2 \\
\hline & $\begin{array}{l}\text { Dil öğrenme } \\
\text { psikolojisi }\end{array}$ & & & & 1 & & & & & & 1 \\
\hline & Toplam & & & & & & & & & $\mathbf{o}$ & 3 \\
\hline
\end{tabular}

Tablo 5’te de görüldüğü gibi YTÖ yüksek lisans programlarındaki zorunlu ve seçmeli dersler, beş tema altında gruplandırılmıştır. YTÖ yüksek lisans programlarındaki derslerin temalara göre dağılımı incelendiğinde programların tamamında öğrencilere; araştırma, kuram ve pedagoji temalarıyla ilgili derslerin sunulduğu görülmektedir. Bu üç temanın, YTÖ yüksek lisans programlarının temel boyutları olarak kabul edildiği görülmektedir. Bunlar arasından araştırma teması altında her programda en az bir zorunlu dersin yer alması ve toplam ders sayısının fazlalığı, YÖK tarafından belirlenen yüksek lisans programı açmaya ilişkin düzenlemelerle ilişkilendirilebilir. Diğer taraftan kuram ve pedagoji temalarında seçmeli ders sayısının fazlalığı dikkat çekmektedir. İlgili temalarda seçmeli derslerin sayısı artırılarak programı geliştirenler/bölüm başkanları/öğretim üyeleri tarafından öğrencilerin bu temalardan ders seçme şanslarını artırmaya yönelik bir politika izlendiği düşünülebilir.

Kuram teması incelendiğinde dil bilimi alt temasına ilişkin her programda zorunlu veya seçmeli derslerin yer aldığı görülmektedir. Hatta kuram teması altındaki tek zorunlu ders de dil bilimi alt temasıyla ilişkilendirilmiştir. Bu ders, Dil Biliminin Temel Kavram ve İlkeleri adı ile 9 Eylül Üniversitesi YTÖ yüksek lisans öğrencileri tarafından zorunlu olarak alınmaktadır. Ayrıca dil edinimi ve söz varlığına ilişkin dersler de incelenen programların çoğunda öğrencilere seçmeli ders olarak sunulmaktadir.

Pedagoji temasında yabancı dilde öğretim yöntem ve tekniklerine ilişkin dersler zorunlu ve seçmeli olarak programlarda yer almaktadır. Öğrencilere, incelenen programların tamamında seçmeli; ikisinde ise hem seçmeli hem zorunlu olarak sunulmaktadır. Ayrıca bu derslerin sayısının da çok fazla olduğu görülmektedir. Örneğin Sakarya Üniversitesinde ikisi zorunlu olmak üzere toplam altı ders öğretim yöntem ve teknikleri ile ilişkilendirilmiştir. Bu dersler şunlardır: Çokdilli Türk Kökenlilere Türkçe Öğretimi, Çağdaş Türk Edebiyatı Metinleri ile Yabancılara Türkçe Öğretimi (Z), Yabancı Dil Olarak Türkçe Öğretimi Yöntemleri (Z), Yabancı Dil Olarak Türkçe Öğretiminde Metindil bilimisel Yaklaşım ve Uygulamalar, Yabancı Dil Olarak Türkçe Öğretiminde Eğitsel Oyunlar, İki Dilli Ortamlarda Anadili Öğretimi. Ayrıca bu dersler arasında yer alan iki dillilik/çok dillilik durumuyla ilişkili dersler de dikkat çekmektedir. İncelenen diğer üniversitelerdeki derslerde buna vurgu yapan bir ders yer almamaktadır.

Öte yandan pedagoji temasında, dilbilgisi ve öğretimi ile dil becerilerinin öğretimi alt temalarıyla ilişkilendirilen ders sayılarının fazlalı̆̆ı da dikkat çekicidir. Örneğin Hacettepe Üniversitesinde YTÖ yüksek lisans programı, dilbilgisi ve öğretimi temasıyla ilişkilendirilebilecek yabancı dil olarak Türkçenin Yapısal Özellikleri I- II ve Yabancı Dil Olarak Türkçe Dilbilgisi üç farklı seçmeli ders olarak öğrencilere sunulmaktadır. Dil becerilerinin öğretimine ilişkin ise Çanakkale Onsekiz Mart Üniversitesi YTÖ yüksek lisans programında sunulan beş seçmeli ders; Yabancı Dil Olarak Türkçe

\footnotetext{
Adres
RumeliDE Dil ve Edebiyat Araştırmaları Dergisi Osmanağa Mahallesi, Mürver Ciceği Sokak, No:14/8 Kadıköy - ISTANBUL / TÜRKIYE 34714 e-posta: editor@rumelide.com tel: +90 $5057958124,+902167730616$ 
Dinleme Öğretimi, Yabancı Dil Olarak Türkçe Okuma Öğretimi, Türkçenin Yabancı Dil Olarak Öğretiminde Yazma Eğitimi, Yabancı Dil Olarak Türkçe Konuşma Öğretimi, Yabancı Dil Olarak Türkçe Yazma Öğretimi şeklinde adlandırılmıştır. Ayrıca pedagoji temasında yabancı dilde öğretim yöntem ve tekniklerine ilişkin bazı derslerin belirli bir özel alana odaklandığı da ifade edilebilir. Hacettepe Üniversitesi YTÖ yüksek lisans programında Türk Dilinin Engellilere Öğretimi; Sakarya Üniversitesi YTÖ yüksek lisans programında Çokdilli Türk Kökenlilere Türkçe Öğretimi; Çanakkale Onsekiz Mart Üniversitesi YTÖ yüksek lisans programında Türk Halk Edebiyatı Ürünleri Aracllığıla Yabancılara Türkçe Öğretimi; Uludağ Üniversitesi YTÖ yüksek lisans programında ise Film Materyaliyle Türkçenin Yabancı Dil Olarak Öğretimi gibi dersler buna örnek olarak gösterilebilir.

Pedagoji teması altında materyal geliştirme/değerlendirme alt temasıyla ilişkilendirilebilecek seçmeli dersler, incelenen programların neredeyse tamamında bulunmaktadır. Bu kapsamdaki zorunlu derslerin tamamının ise aynı üniversite tarafından bu alt temayla ilişkili şekilde yapılandırıldığı görülmektedir. Sakarya Üniversitesi YTÖ yüksek lisans programının sunduğu bu dersler; Yabancı Dil Olarak Türkçe Ders Kitabı İncelemeleri ve Yabancılar İçin Türkçe Öğretimi Metin İncelemeleri'dir. Yine pedagoji teması altında incelenen üniversitelerin yalnızca dördünde toplam beş farklı derste öğretim teknolojileri alt temasıyla ilgili dersler bulunmaktadır. Bu derslere, Yabancı Dil olarak Türkçe öğretiminde Eğitim Teknolojilerinin Kullanımı (İstanbul Üniversitesi), Teknoloji Destekli Dil Öğretimi (Nevşehir Hacı Bektaş Veli Üniversitesi) örnek verilebilir.

Sosyoloji teması altında kültür alt temasıyla ilişkilendirilebilecek seçmeli dersler, incelenen üniversitelerin neredeyse tamamında $(\mathrm{n}=8)$ bulunmaktadır. Kültür alt temasıyla ilişkilendirilen derslerin Çanakkale ve Hacettepe üniversitelerindeki YTÖ yüksek lisans programlarında sayıca fazla olması dikkat çekicidir. Çanakkale Onsekiz Mart Üniversitesi YTÖ yüksek lisans programında; Yabancı Dil Olarak Türkçe Öğretiminde Hedef Kültür, Yabancllara Türkçe Öğretiminde Türk Kültür ve Uygarlı̆̆ı; Hacettepe Üniversitesi YTÖ yüksek lisans programında ise Kültür ve Dil Öğretimi, Türk Dili ve Kültürünün Evreleri dersleri örnek gösterilebilir.

İncelenen programlarda psikoloji temasıyla ilişkilendirilen dersler, programlar arasında yaygınlık ve benzerlik göstermemektedir. Yalnızca üç üniversitede psikoloji temasıyla ilişkilendirilen üç farklı ders bulunmaktadır.

Araştırma kapsamında on üniversitedeki yabancılara İngilizce öğretimi yüksek lisans programlarına ait 119 ders incelenmiştir. Bu derslerin belirlenen temalara göre dağılımı ve zorunlu ve seçmeli ders sayıları Tablo 6'da sunulmuştur:

Tablo 6. Yabancılara İngilizce öğretimi yüksek lisans programlarındaki zorunlu ve seçmeli derslerin temalara göre dağılımı

\begin{tabular}{|c|c|c|c|c|c|c|c|c|c|c|c|c|c|c|c|c|c|c|c|c|}
\hline \multicolumn{2}{|c|}{ ÜNIVERSITELER } & \multirow{2}{*}{$\frac{\sum_{0}^{n}}{Z}$} & \multirow{2}{*}{$\mathbf{S}$} & \multirow{2}{*}{ 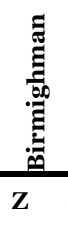 } & \multicolumn{3}{|c|}{$\begin{array}{l}3 \\
\text { o } \\
\text { है } \\
\frac{\pi}{0} \\
\end{array}$} & 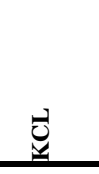 & 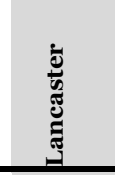 & \multicolumn{2}{|c|}{ 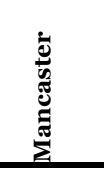 } & \multicolumn{2}{|c|}{ שี } & \multicolumn{3}{|c|}{ כ) } & \multicolumn{2}{|c|}{$\ddot{z}$} & \multicolumn{2}{|c|}{ हี } \\
\hline TEMALAR & $\begin{array}{l}\text { ALT } \\
\text { TEMALAR }\end{array}$ & & & & $\mathbf{S}$ & $\mathbf{Z}$ & $\mathbf{S}$ & $\mathbf{Z}$ & $\mathbf{Z}$ & $\mathbf{Z}$ & $\mathbf{S}$ & $\mathbf{Z}$ & $\mathbf{S}$ & $\mathbf{Z}$ & $\mathbf{Z}$ & $\mathbf{S}$ & $\mathbf{Z}$ & $\mathbf{S}$ & $\mathbf{Z}$ & $\mathbf{S}$ \\
\hline \multirow[t]{3}{*}{ Araştırma } & $\begin{array}{l}\text { Bilimsel } \\
\text { araştırma }\end{array}$ & 1 & & 1 & & 1 & 1 & 1 & 1 & 1 & 1 & & 1 & 1 & 1 & 2 & 2 & & 10 & 5 \\
\hline & \multicolumn{8}{|l|}{ Toplam } & & & & & & & & & & & 10 & 5 \\
\hline & \multicolumn{8}{|c|}{$\begin{array}{r}\text { Adres } \\
\text { RumeliDE Dil ve Edebiyat Araştırmaları Dergisi } \\
\text { Osmanağa Mahallesi, Mürver Çiçeği Sokak, No:14/8 } \\
\text { Kadıköy - İSTANBUL / TÜRKIYE } 34714 \\
\text { e-posta: editor@rumelide.com } \\
\text { tel: }+905057958124,+902167730616\end{array}$} & \multicolumn{10}{|c|}{$\begin{array}{l}\text { Address } \\
\text { RumeliDE Journal of Language and Literature Studies } \\
\text { Osmanağa Mahallesi, Mürver Çiçeği Sokak, No:14/8 } \\
\text { Kadıköy - ISTANBUL / TURKEY } 34714 \\
\text { e-mail: editor@rumelide.com, } \\
\text { phone: +90 505 7958124, +90 } 216773 \text { o } 616\end{array}$} & & \\
\hline
\end{tabular}


76 / RumeliDE Journal of Language and Literature Studies 2021.23 (June)

A comparative analysis of master's degree programs on teaching Turkish and English to speakers of other languages / G. Aydın; E.İlhan (pp. 65-86)

\begin{tabular}{|c|c|c|c|c|c|c|c|c|c|c|c|c|c|c|c|c|c|c|c|c|c|}
\hline \multirow{5}{*}{ Kuram } & Dil bilimi & 1 & & 1 & 6 & 1 & 2 & & 3 & 1 & & 1 & 1 & & 1 & 3 & 1 & 1 & 2 & 9 & 15 \\
\hline & Dil edinimi & 1 & 1 & & & & & & 1 & & & & 1 & 1 & 1 & 1 & & & 2 & 3 & 6 \\
\hline & $\begin{array}{l}\text { Dilin gelişimi } \\
\text { ve yayılımı }\end{array}$ & & & & 1 & & & & & & & & & & 1 & & & & 1 & & 3 \\
\hline & Söz varlığ & & & & 2 & & & & & & & & & & & & & & & & 2 \\
\hline & Toplam & & & & & & & & & & & & & & & & & & & 12 & 26 \\
\hline \multirow{11}{*}{ Pedagoji } & $\begin{array}{l}\text { Öğretim } \\
\text { yöntem ve } \\
\text { teknikleri }\end{array}$ & 2 & 3 & 2 & 3 & 4 & 6 & 2 & 5 & 2 & 1 & 2 & 1 & 3 & 1 & 1 & 3 & 1 & 2 & 17 & 25 \\
\hline & $\begin{array}{l}\text { Öğretim } \\
\text { teknolojileri }\end{array}$ & & 1 & & & & & & 1 & & 1 & 2 & & 1 & & & 1 & & 1 & 1 & 7 \\
\hline & $\begin{array}{l}\text { Dil } \\
\text { becerilerinin } \\
\text { öğretimi }\end{array}$ & & & & 3 & & & & 1 & & & 1 & & & 1 & & & & & & 6 \\
\hline & $\begin{array}{l}\text { Materyal } \\
\text { geliştirme/ } \\
\text { değerlendirme }\end{array}$ & & 1 & & & 1 & & & 1 & & & 1 & & 1 & 1 & & & & & 1 & 5 \\
\hline & $\begin{array}{l}\text { Ölçme- } \\
\text { değerlendirme }\end{array}$ & & 1 & & & 1 & & & 1 & 1 & & & 1 & 1 & 1 & & 1 & & 1 & 3 & 5 \\
\hline & $\begin{array}{l}\text { İki/çok dillilik } \\
\text { ve öğretimi }\end{array}$ & & & & 1 & & & & 1 & & & & & & 1 & & & & 1 & & 4 \\
\hline & $\begin{array}{l}\text { Program } \\
\text { geliştirme }\end{array}$ & & & 1 & & 1 & & & 1 & 1 & & 1 & 1 & & & & & & 1 & 4 & 3 \\
\hline & $\begin{array}{l}\text { Dil bilgisi ve } \\
\text { öğretimi }\end{array}$ & & & & 3 & & & & & & & & & & & & & & & & 3 \\
\hline & $\begin{array}{l}\text { Öğrretmen } \\
\text { eğitimi }\end{array}$ & & & & & & & & 1 & & & 1 & & & & & 1 & & & & 3 \\
\hline & $\begin{array}{l}\text { Gözlem- } \\
\text { uygulama }\end{array}$ & & & & & & 1 & & & & & & & & & & 1 & 1 & & 1 & 2 \\
\hline & Toplam & & & & & & & & & & & & & & & & & & & $\mathbf{2 7}$ & 63 \\
\hline \multirow[t]{7}{*}{ Sosyoloji } & Kültür & & & & 2 & & & & 1 & & & 1 & & & 2 & & 1 & & & & 7 \\
\hline & İletişim & & & & 2 & & & & & & & & & & 2 & & & & & & 4 \\
\hline & Dil ve kimlik & & & & & & 1 & & 1 & & & & & & & & & & & & 2 \\
\hline & Göç-çeşitlilik & & & & 1 & & & & 1 & & & & & & & & & & & & 1 \\
\hline & Dil ve medya & & & & 1 & & & & & & & & & & & & & & & & 1 \\
\hline & Dil ve güç & & & & & & & & 1 & & & & & & & & & & & & 1 \\
\hline & Toplam & & & & & & & & & & & & & & & & & & & $\mathbf{o}$ & 16 \\
\hline \multirow[t]{3}{*}{ Psikoloji } & $\begin{array}{l}\text { Dil öğrenme } \\
\text { psikolojisi }\end{array}$ & & & & 1 & & & & & & & 1 & 1 & & & & & & 1 & & 4 \\
\hline & Motivasyon & & & & & & & & & & & & & & & & 1 & & & & 1 \\
\hline & Toplam & & & & & & & & & & & & & & & & & & & $\mathbf{o}$ & 5 \\
\hline \multirow[t]{4}{*}{ Diğer } & $\begin{array}{l}\text { Edebiyat } \\
\text { drama }\end{array}$ & & & & & & & & & & & & & & & & 1 & & & & 1 \\
\hline & Okur yazarlık & & & & & & 1 & & & & & & & & & & & & & & 1 \\
\hline & $\begin{array}{l}\text { Eğitim } \\
\text { felsefesi }\end{array}$ & & & & & & 1 & & & & & & & & & & & & & & 1 \\
\hline & Toplam & & & & & & & & & & & & & & & & & & & $\mathbf{o}$ & 3 \\
\hline
\end{tabular}

Tablo 6'da da görüldüğü üzere Yiö yüksek lisans programlarındaki zorunlu ve seçmeli dersler, altı tema altında gruplandırılmıştır. YiöÖ yüksek lisans programlarındaki derslerin temalara göre dağılımı incelendiğinde tamamında öğrencilere; pedagoji, kuram ve araştırma temalarıly ilgili derslerin sunulduğu görülmektedir. Bu üç tema, YíÖ yüksek lisans programlarının temel boyutları olarak

RumeliDE Dil ve Edebiyat Araștırmaları Dergisi Osmanağa Mahallesi, Mürver Ciçeği Sokak, No:14/8 Kadıköy - İSTANBUL / TÜRKIYE 34714 e-posta: editor@rumelide.com tel: +90 505 7958124, +90 2167730616
Address

RumeliDE Journal of Language and Literature Studies

Osmanağa Mahallesi, Mürver Çiçeği Sokak, No:14/8

Kadıköy - ISTANBUL / TURKEY 34714

e-mail: editor@rumelide.com,

phone: +90 505 7958124, +90 2167730616 
belirlenmiştir. Ayrıca incelenen programların çoğunda (n=8) araştırma temasıyla ilgili en az bir zorunlu ders bulunmaktadır.

Kuram teması altında dil bilimi alt temasına ilişkin incelenen programların neredeyse tamamında $(\mathrm{n}=9)$ zorunlu derslerin; toplam 15 adet de seçmeli dersin yer aldığ görülmektedir. Özellikle Birmingham Üniversitesi YïÖ yüksek lisans programında bir zorunlu dersin yanı sıra toplam 12 seçmeli dersin altısı dil bilimi alt temasıyla ilişkilendirilebilir. Bu derslerden bazıları şunlardır; Sosyodil bilimi (Sociolinguistics), Bütünce dil bilimii (Corpus Linguistics), YiöÖde Psikodil bilimi (Psycholinguistics in TESOL). İncelenen YïÖ yüksek lisans programlarında dil edinimi alt teması ile ilişkilendirilen derslerden üçünün zorunlu olduğu görülmektedir. Dil bilimi ve dil edinimi alt temalarıyla ilişkilendirilen zorunlu derslerin fazlalığı, bu konulara verilen önemi göstermektedir.

İncelenen programlardaki dersler en fazla pedagoji teması ile ilişkili olarak yapılandırılmıştır. Öğretim yöntem ve teknikleri alt temasına ilişkin ise en az bir ve en çok dört olmak üzere zorunlu dersler bulunmaktadır. Bu zorunlu derslerin toplam sayısındaki fazlalığın $(n=17)$ yanı sıra 25 seçmeli dersin bulunması dikkat çekicidir.

İncelenen programların neredeyse tamamında ölçme ve değerlendirme alt teması; yarısından fazlasında da öğretim teknolojileri ve program geliştirme alt temalarıla ilişkili dersler bulunmaktadır. Program geliştirme alt temasıyla ilgili dört zorunlu ders dikkat çekicidir. Bu derslere, YİÖ'de Pedagoji ve Eğitim/Öğretim Programı (Pedagogy and Curriculum in TESOL-Bristol Uni.) ve YİÖ için İlkeli Materyaller ve Ders Tasarımı (Principled Materials and Course Design for TESOLMancaster Uni.) örnek gösterilebilir. Ölçme ve değerlendirme alt temasıyla ilgili üç zorunlu derse ise Dil, Yeterlilik, Değerlendirme ve Dönüt (Language Proficıency, Assessment And Feedback- Glasgow Uni.) ile Sınıf-içi Dil Düzeyi Değerlendirme (Classroom Language Assesment- Lancaster Uni.) dersleri örnek verilebilir.

Sosyoloji teması ise özellikle kültür ve iletişim alt temalarına ilişkin seçmeli derslerin sayısı fazladır. Ayrıca dil ve kimlik, göç-çeşitlilik, dil ve medya, dil ve güç gibi alt temalarla ilişkili dersler de dikkat çekicidir. Öte yandan bu dersler incelenen programlar arasında yaygınlık ve benzerlik göstermemektedir. Üniversitelerde psikoloji ve diğer gibi temalar altında sunulan dersler ise incelenen programlar arasında yaygınlık ve benzerlik göstermemektedir. Dört farklı üniversitede psikoloji temasıyla ilişkilendirilen üç farklı ders bulunmaktadır. Diğer teması altında ise Warwick YïÖ yüksek lisans programında; YIOÖ'de Edebiyat ve Drama (Literature and Drama in TESOL), Glasgow YİÖ yüksek lisans programında da Okuryazarlık (Literacy) adlı dersler yer almaktadır.

\subsection{Zorunlu derslerin ilişkili olduğu alt temaların YTö ve Yï̈ yüksek lisans programlarına göre dağılımı}

Araştırma kapsamına dâhil edilen yüksek lisans programlarında zorunlu olan derslerin ilişkili olduğu alt temaların YTÖ ve YïÖ yüksek lisans programlarına göre dağılımı Şekil ı'de görülmektedir.

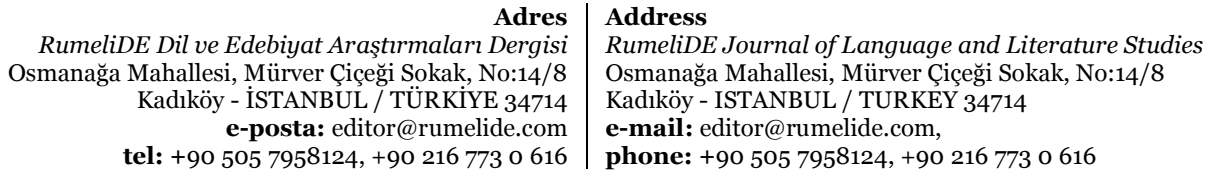

tel: +90 $5057958124,+902167730616$ 


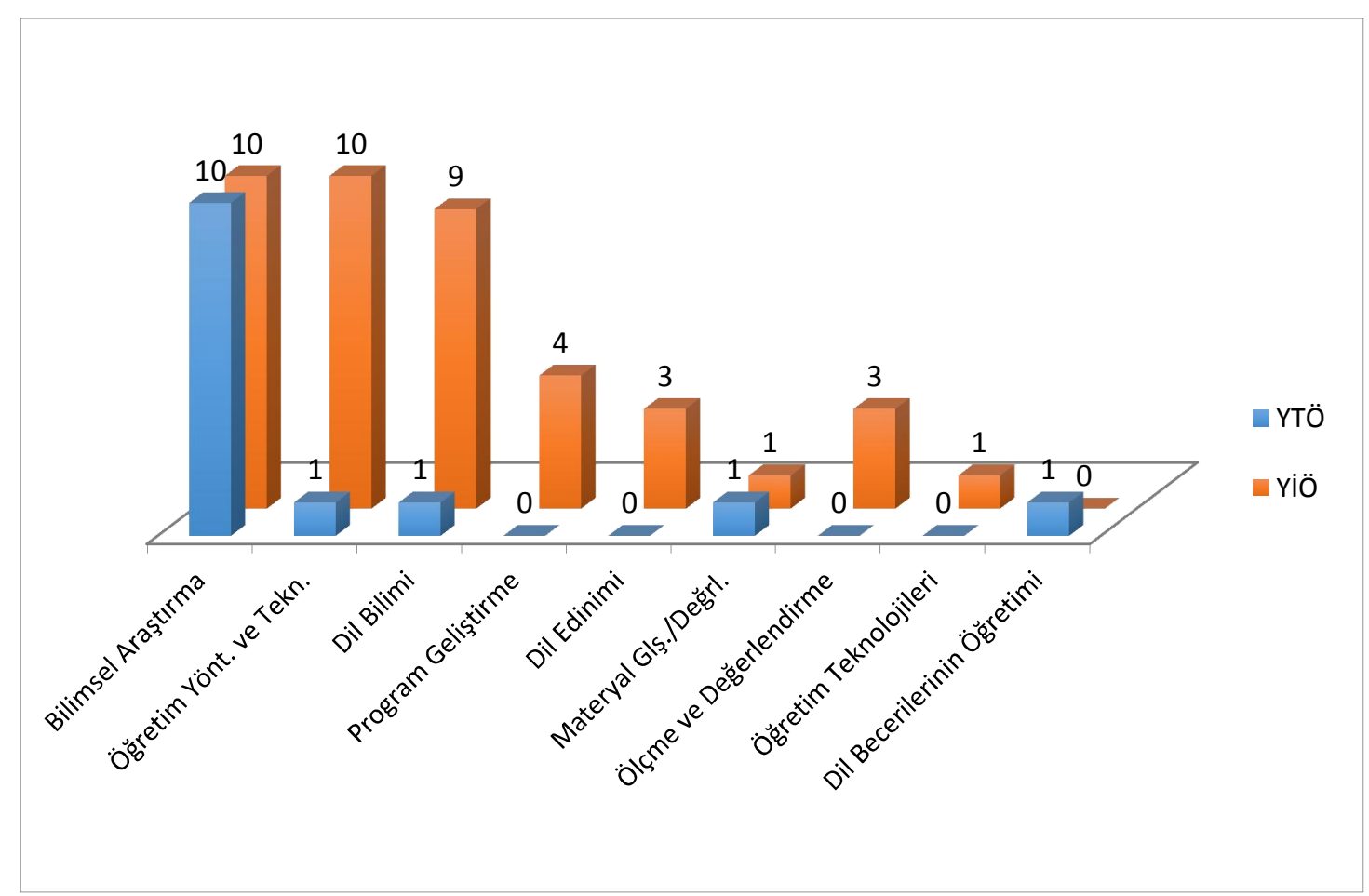

Şekil 1. Yüksek lisans programlarının zorunlu alt temalarının ilişkili olduğu derslerin YTÖ ve YİÖ yüksek lisans programlarına göre dağılımı

Bilimsel araştırma alt temasına ilişkin dersler hem YTÖ hem de YïÖ yüksek lisans programlarının tamamında zorunlu olarak bulunmaktadır. YTÖ yüksek lisans programlarında bilimsel araştırmaya yapılan vurgunun YİÖ yüksek lisans programlarıyla benzer olduğu görülmektedir. Öğretim yöntem ve teknikleri alt temasına ilişkin dersler yalnızca bir YTÖ yüksek lisans programında zorunlu olarak yer alırken; YïÖ yüksek lisans programlarının tamamında ilgili dersler yer almaktadır. Öte yandan bu alt temaya ilişkin vurgunun bir önceki Tablo 6'da görüldüğü gibi seçmeli dersler ile sağlanmaya çalışıldığı ifade edilebilir.

Dil bilimi alt temasına ilişkin zorunlu dersler, YTÖ yüksek lisans programlarının yalnızca birinde; YíÖ yüksek lisans programlarının ise yarısından fazlasında bulunmaktadır. Bu açıdan incelenen YTÖ ve YİÖ yüksek lisans programlarının farklılaştı̆̆ı belirtilebilir. Ayrıca program geliştirme, ölçme ve değerlendirme ile dil edinimi alt temalarına ilişkin de benzer şekilde YTÖ ve YİÖ yüksek lisans programları farklılaşmaktadır. YTÖ yüksek lisans programlarının hiçbirinde bu alt temalara ilişkin zorunlu bir ders bulunmazken YïÖ yüksek lisans programlarının bazılarında bu temalarla ilişkili zorunlu dersler yer almaktadır. Bunun tam tersi bir durum ise dil becerilerinin öğretimi için geçerlidir. YİÖ yüksek lisans programlarının hiçbirinde bu alt temaya ilişkin zorunlu ders yer almazken; YTÖ yüksek lisans programlarının birinde zorunlu dersler yer almaktadır.

\subsection{Seçmeli derslerin ilişkili olduğu alt temaların YTÖ ve Yïö yüksek lisans programlarına göre dağılımı}

Yüksek lisans programlarında seçmeli derslerin en çok ilişkilendirildiği alt temaların YTÖ ve YIOÖ yüksek lisans programlarındaki dağılımı Şekil 2 ve Şekil 3’te gösterilmektedir. Bu dağılım ve karşılaştırmalar yapılırken ders sayıları yerine derslerin tüm seçmeli dersler içerisindeki yüzdelik oranları temel alınmıştır.

\begin{tabular}{r|l} 
Adres & Address \\
RumeliDE Dil ve Edebiyat Araştırmalarn Dergisi & RumeliDE Journal of Language and Literature Studies \\
Osmanağa Mahallesi, Mürver Çiçeği Sokak, No:14/8 & Osmanağa Mahallesi, Mürver Çiçeği Sokak, No:14/8 \\
Kadıköy - İSTANBUL / TÜRKIYE 34714 & Kadıköy - ISTANBUL / TURKEY 34714 \\
e-posta: editor@rumelide.com & e-mail: editor@rumelide.com, \\
tel: +90 505 7958124, +90 216 773 0 616 & phone: +90 505 7958124, +90 2167730616
\end{tabular}




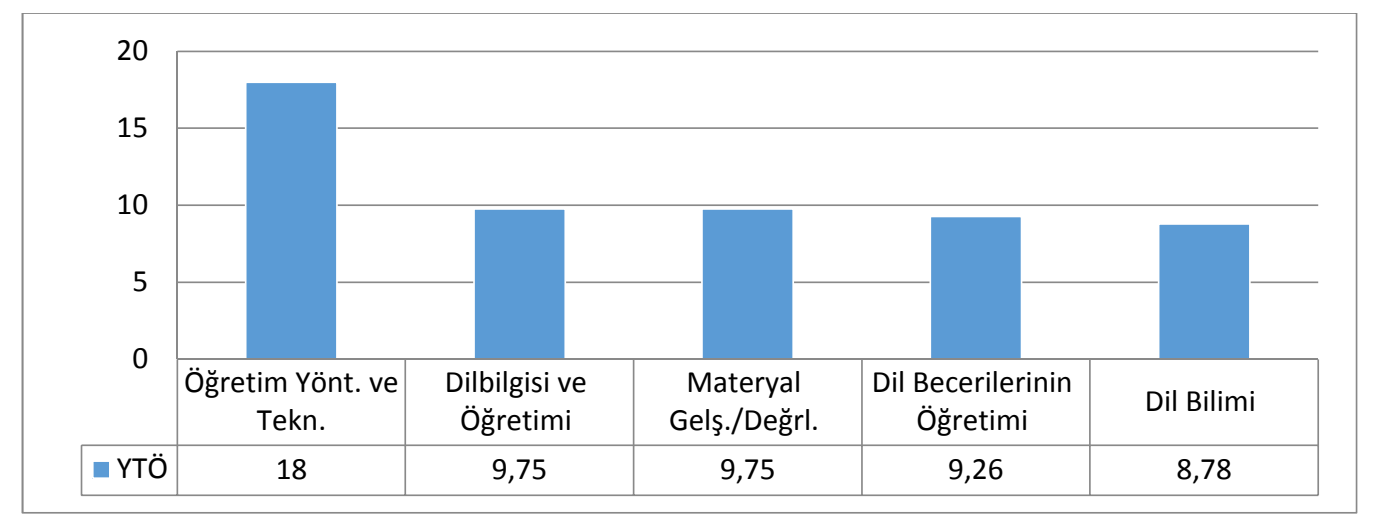

Şekil 2. YTÖ yüksek lisans programlarında seçmeli derslerin en yüksek oranda ilişkilendirildiği alt temalar

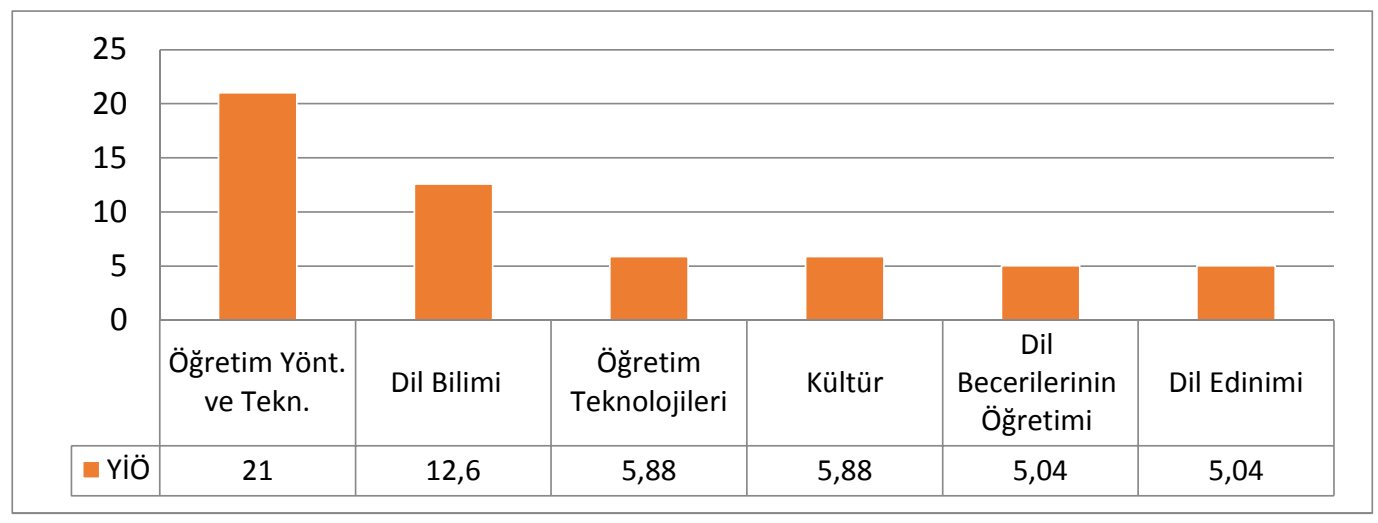

Şekil 3. YïÖ yüksek lisans programlarında seçmeli dersin en yüksek oranda ilişkilendirildiği alt temalar

YTÖ ve YİÖ yüksek lisans programlarının her ikisinde de öğretim yöntem ve teknikleri alt temasına ilişkin seçmeli derslerin oranı en yüksektir. Oranı en yüksek olan ilk beş ders ve ilk altı ders arasında ortak olan diğer alt temalar dil bilimi ve dil becerilerinin öğretimidir. Bunlar haricinde YTÖ yüksek lisans programlarında dil bilgisi ve öğretimi alt temasına ilişkin derslerin oranının oldukça yüksek olduğu; yine benzer şekilde YïÖ yüksek lisans programında da ilk beşte yer aldığı görülmektedir. Ayrıca YTÖ yüksek lisans programlarında materyal geliştirme-değerlendirmeyle ilişkili derslerin oranının yüksek olduğu, öte yandan Yi̇̈ yüksek lisans programlarında da öğretim teknolojilerine ilişkin derslerin oranının yüksek olduğu belirlenmiştir. Bunların haricinde YíÖ yüksek lisans programlarında seçmeli ders oranlarının en yüksek olduğu alt temalar arasında kültür ve dil ediniminin olması da YTÖ ile YİÖ yüksek lisans programlarını birbirinden farklı hale getirmektedir.

\section{Sonuç, tartıșma ve öneriler}

Bu araştırmada Türkiye'de her geçen gün gerekliliği daha fazla hissedilen ve buna bağlı olarak yaygınlaşan yabancılara Türkçe öğretimi yüksek lisans programları ile bilimsel birikim açısından oldukça köklü olan İngiltere'deki yabancılara İngilizce öğretimi yüksek lisans programlarında yer alan zorunlu/seçmeli dersler karşılaştırmalı olarak incelenmiştir. Bu inceleme sonuçlarından belirlenen benzerlik/farklılıklar, daha nitelikli yüksek lisans programlarının geliştirilmesi için temel bir çerçeve oluşturmaya yardımcı olacak niteliktedir.

\footnotetext{
Adres $\mid$ Address

RumeliDE Dil ve Edebiyat Araşttrmaları Dergisi $\quad$ RumeliDE Journal of Language and Literature Studies Osmanağa Mahallesi, Mürver Çiçeği Sokak, No:14/8 Osmanağa Mahallesi, Mürver Çiçeği Sokak, No:14/8

Kadıköy - İSTANBUL / TÜRKIYE 34714 Kadıköy - ISTANBUL / TURKEY 34714 e-posta: editor@rumelide.com e-mail: editor@rumelide.com,

tel: +90 505 7958124, +90 2167730616 phone: +90 505 7958124, +90 2167730616
} 
A comparative analysis of master's degree programs on teaching Turkish and English to speakers of other languages / G. Aydın; E.İlhan (pp. 65-86)

İncelenen YTÖ yüksek lisans programlarının ders döneminde almak zorunda olunan toplam ders sayıları altı ile on arasında, YïÖ yüksek lisans programlarının ise dört ile dokuz arasında değişiklik göstermektedir. Ders çeşitliliğinin fazlalığı, disiplinlerarasılığı gerektiren bu bölümler için farklı bakış açılarını destekleyecek/geliştirecek bilgi, beceri ve yetkinliklerin kazandırılması açısından oldukça önemlidir. Programlardaki zorunlu ders sayıları YTÖ için iki ile beş arasında, YïÖ için bir ile altı arasında değişmektedir. YïÖ yüksek lisans programlarında yer alan zorunlu dersler tamamen programın öğretim üyeleri tarafından belirlenirken YTÖ'de hem programın öğretim üyelerinin belirlediği hem de YÖK tarafından programa konan "araştırma teknikleri ve yayın etiği” ile ilgili dersler mevcuttur. Türkiye'de 2016'dan sonra programlara bir üst müdahalenin olmasının bilimsel araştırma ve etik konularına ilişkin farkındalık yaratmak adına somut bir adım olduğu düşünülse de bir uygulama birliğinin olmadığı, evrensel kod ve ilkeler doğrultusunda içerikler oluşturulması gerektiği belirtilmektedir (Daştan, Bayraktar ve Bellikli, 2019).

Programlarda sunulan seçmeli ders sayılarının YTÖ için sekiz ile yirmidokuz; YIOÖ için ise beş ile oniki arasında değiştiği, ancak bir YïÖ yüksek lisans programında hiçbir seçmeli ders sunulmadığı tespit edilmiştir. YTÖ yüksek lisans programlarıyla YİÖ programları arasında nicelik olarak ciddi bir fark olduğu görülmektedir. Zorunlu dersler, eğitim sürecinde öğrenilmesi gereken temel bilgi ve becerileri içerirken seçmeli dersler, ilgi ve yeteneklere göre tercih edilebilir olması yönüyle alternatifler yaratır, olumlu tutum geliştirir. Ancak alternatiflerin de alan uzmanlığı, fiziksel ve zihinsel altyapı gibi bazı temel ölçütler çerçevesinde oluşturulması önemlidir. Buna göre Bologna süreciyle birlikte YÖK'ün 2010 yılında verdiği talimatla programlardaki derslerin en az \%25’inin seçmeli olması gerektiği bilgisi, oransal artışın temel tetikleyicisi olurken program yeterlilikleriyle çelişebilecek çeşitlilikte seçimlik dersin ortaya çıkması problemini de doğurmuştur (Toprak ve Erdoğan, 2013). YTÖ yüksek lisans programlarındaki seçmeli ders sayısının fazlalı̆̆ının, bir öğretim üyesinin açtığı birkaç farklı dersten birinin seçilme oranını artırmak için mi yoksa tamamen alana ivme kazandıracak bir gereksinimden, alt uzmanlık alanlarını zenginleştirme amacından veya programdaki kadroların durumundan mı kaynaklandığı tartışmaya açıktır. Aynı şekilde YïÖ yüksek lisans programlarındaki sınırlı seçmeli ders sayılarının da bu kapsamda üzerinde düşünülmesi gerekmektedir.

Hem YTÖ hem de YiÖ yüksek lisans programlarında dersler tematik olarak beş temada toplanmıştır. YTÖ için 205 dersin, YIÖ için 119 dersin incelenmesi sonucunda araştırma, kuram, pedagoji, sosyoloji ve psikoloji temaları ile bunlara bağlı pek çok alt tema ortaya çıkmıştır. Hem YTÖ hem YİÖ yüksek lisans programları tematik olarak sırasıyla pedagoji, kuram ve araştırma üzerine yapılandırılmıştır. YİÖ yüksek lisans programlarında beş ortak tema ile ilişkilendirilemeyen dersler diğer teması altında toplanmıştır.

Araştırma temasında YTÖ yüksek lisans programlarında en az bir ders, YİÖ yüksek lisans programlarında ise en az bir ders zorunludur. YTÖ programlarındaki toplam zorunlu ders sayısı 20, seçmeli ders sayısı beş iken YíÖ programlarında toplam zorunlu ders sayısı 10, seçmeli ders sayısı beştir. YTÖ ile YIÖ yüksek lisans programlarındaki araştırma temasına ilişkin derslerin sayılarındaki buna benzer bir farklılaşma İngiltere ve Amerika'daki YïÖ yüksek lisans programları arasında da belirlenmiştir (Li, 2014). Her ne kadar niceliksel olarak bir farklılaşma olsa da programların tamamında araştırma ile ilişkilendirilen derslerin olması bu programların genel amaçlarına uygundur. Pek çok çalışmada bilimsel araştırma yöntemleri ve yayın etiği ile ilgili derslerin programlardaki önemi vurgulanmaktadır (Aslan, 2010; Aslan ve Karagül, 2016; Daştan, Bayraktar ve Bellikli, 2019). Tuzcu (2003) lisansüstü programların kişilere bağımsız araştırma yapma, bilimsel olayları geniş ve derin bakış açısı ile irdeleyerek yorumlama ve yeni sentezlere ulaşma yeteneği kazandırdığı belirtmektedir.

\begin{tabular}{r|l} 
Adres & Address \\
RumeliDE Dil ve Edebiyat Arasturmalart Dergisi & RumeliDE
\end{tabular} Osmanağa Mahallesi, Mürver Çiçeği Sokak, No:14/8 Osmanağa Mahallesi, Mürver Çiçeği Sokak, No:14/8 Kadıköy - İSTANBUL / TÜRKIYE 34714 Kadıköy - ISTANBUL / TURKEY 34714 e-posta: editor@rumelide.com e-mail: editor@rumelide.com,

tel: +90 505 7958124, +90 2167730616 phone: +90 505 7958124, +90 2167730616 
YTÖ programlarındaki ders sayısının fazlalı̆ğ bu açıdan düşünüldüğünde uzun vadede araştırma kültürü gelişmiş bireylerin yetişmesi anlamına gelmektedir.

Kuram temasında YTÖ yüksek lisans programlarında sadece bir zorunlu, 40 seçmeli ders; YİÖ yüksek lisans programlarında 12 zorunlu, 26 seçmeli ders bulunmaktadır. Zorunlu dersler ağırlıklı olarak dil biliminde yoğunlaşmaktadır. YTÖ programlarında bir zorunlu ders, YİÖ programlarında dokuz zorunlu ders dil bilimi alt temasıyla ilişkilendirilmiştir. Ayrıca YTÖ’de 18 seçmeli ders, YiÖ'de 15 seçmeli ders de dil bilimi alt temasına yöneliktir. Aslan (2010) araştırmasında dil bilimiyle ilgili derslerin yetersizliğinin terminolojiyi anlama ve kullanma konusunda sorun yarattığını belirtmekte, zorunlu ya da seçmeli olarak Türkçe eğitimi lisansüstü programlarında daha fazla bulunması gerektiğini ifade etmektedir. Bu durum YTÖ programlarında dil biliminin (özellikle zorunlu dersler boyutunda) ötelendiği ve bunun sorun yaratabileceği anlamına gelmektedir. YİÖ programlarının bu anlamda zengin olduğu söylenebilir. YïÖ programlarında dil edinimi ile ilişkilendirilmiş üç zorunlu, altı seçmeli ders; YTÖ programlarında ise dil edinimi ile ilgili zorunlu herhangi bir ders olmamakla birlikte sekiz seçmeli ders bulunmaktadır. Söz varhğı alt teması ile ilgili YTÖ'de sekiz seçmeli ders, YİÖ'de ise iki seçmeli ders olması dikkat çekicidir.

Pedagoji temasında YTÖ yüksek lisans programlarında öğretim yöntem ve teknikleri alt temasıyla ilişkilendirilen dört zorunlu, 38 seçmeli ders; YİÖ yüksek lisans programlarında ise 17 zorunlu, 25 seçmeli ders bulunmaktadır. Yabancı bir dilin nasıl öğretileceğine ilişkin yöntem ve tekniklerin öğrenilmesi tercihe bırakılmayacak kadar önemsenmesi gerekir. Lin (2010) YïÖ, Liu ve Pan (2018) de yabancılara Çince öğretimi yüksek lisans programlarına ilişkin gerçekleştirdikleri kapsamlı program değerlendirme çalışmaları sonucunda yabancılara İngilizce/Çince öğretimi yüksek lisans programlarının öğrencilerinin pedagojik bilgi/becerilerini geliştirmesi gerektiğini vurgulamıştır. Bu nedenlerle, programın özü olarak kabul edilen bu derslerin YTÖ'de zorunlu olarak az sayıda yer alması önemli bir eksiklik olarak değerlendirilebilir. Özbay ve Bahar (2016) YTÖ’de eğitim ve öğretimle ilgili herhangi bir ders almayan alan uzmanlarının (Türk dili ve edebiyatı vb.) dil öğretim yöntem ve teknikleri konusunda ciddi sıkıntılar yaşadığını; Katerinov (1984) ise yabancı dilin genel olarak öğretim bilgisi (didaktik) ve eğitimbilim (pedagoji) ile ilgilenenlerce öğretilmesinin önemini belirtmektedir. Bugün YTÖ lisansüstü eğitim programlarında da alanın pedagoji temasında zorunlu ders sayısının artılması ve bu derslerin alanında uzman akademisyenlerce verilmesi sağlanmalıdır. Bunun yanında YTÖ'de dilbilgisi ve öğretimi, materyal geliştirme/ değerlendirme, dil becerilerinin öğretimi ile öğretim teknolojileri alt temaları ön plana çlkarken Yiö’̉de ölçme ve değerlendirme, öğretim teknolojileri, program geliştirme, dil becerilerinin öğretimi ve materyal geliştirme/değerlendirme alt temaları ön plana çımaktadır. Dilbilgisi ve öğretimi ile ilişkilendirilen dersler YIÖO'de geri plana itilirken, ölçme ve değerlendirme ve program geliştirme ile ilişkilendirilen derslerin de YTÖ'de geri plana itilmesi söz konusudur. Dilbilgisinin bir beceri alanı olarak görülmemesinden dolayı YïÖ programlarında çok az yer alması, beklenen bir durumdur. YTÖ programlarında da kural öğretmeyi esas alan bu derslerin azaltılması daha doğru bir yaklaşım olabilir. Programın etkili bir şekilde uygulanabilmesinin temel ölçütlerinden oluşturan program geliştirmenin yok denecek kadar az ve ölçme değerlendirmenin de çok sınırlı dersle ilişkilendirildiği YTÖ yüksek lisans programlarında, asıl sorunun alan uzmanı yetersizliğinden kaynaklandığı düşünülmektedir. YTÖ yüksek lisans programlarının disiplinlerarası niteliği göz önünde bulundurulduğunda bu sorunu çözmek için özellikle eğitim bilimleri çatısı altında ayrı uzmanlık alanları gerektiren program geliştirme ve ölçme ve değerlendirme uzmanlarından yararlanılmalıdır.

\footnotetext{
Adres
RumeliDE Dil ve Edebiyat Araşttrmaları Dergisi Osmanağa Mahallesi, Mürver Ciçeği Sokak, No:14/8 Kadıköy - İSTANBUL / TÜRKIYE 34714 e-posta: editor@rumelide.com tel: +90 $5057958124,+902167730616$ 
A comparative analysis of master's degree programs on teaching Turkish and English to speakers of other languages / G. Aydın; E.İlhan (pp. 65-86)

Hem YTÖ hem YiÖ yüksek lisans programlarında kuram ve pedagoji temalarında seçmeli dersler ağırlıklıdır. Kuram temasında YTÖ'de 40, YİÖ'de 26 seçmeli; pedagoji temasında YTÖ’de 116, YïÖ'de 63 seçmeli ders bulunmaktadır. YTÖ'deki seçmeli ders yoğunluğu, Ottekin-Demirbolat'ın (2005) yüksek lisans programlarında seçmeli ders sayısının artırılması önerisini destekler niteliktedir. Seçmeli ders sayısının fazla olması, yüksek lisans programlarının öğrencilerin uzmanlaşmak istedikleri özel bir alana yoğunlaşmasını sağlaması açısından da beklentilere uygundur. Öğrencilerin ilgi, ihtiyaç ve yeteneklerine göre belirleyecekleri alanda uzmanlaşmaları için onlara sunulan ders sayısı fazla olmalıdır (Hedges, Pacheco ve Webber, 2014).

Sosyoloji temasında YTÖ ve YÏÖ yüksek lisans programlarının özellikle kültür alt temasıyla ilişkilendirilebilecek derslere ağırlık verdiği, bunu iletişim alt temasının takip ettiği tespit edilmiştir. Dili bağlamında, içinde bulunduğu kültürle öğretmenin, etkili ve kalıcı öğrenmeler sağladığından yola çlkarak öğrenenin kültürü ile öğrenilen dilin kültürü arasında yeni bir “üçüncü yer” yaratmak gerekmektedir (Bhabha, 1988; Kovacs, 2017; Kramsch, 1993). Lisansüstü programlarda da "üçüncü yer"i inşaa etmenin önemi vurgulanmaktadır (Ilieva, Li \& Li, 2015; Ilieva \& Ravindran, 2018). Cortazzi ve Jin (1999) de yabancılara dil öğretimine odaklanan programlara kültürel ögelerin dengeli bir şekilde dahil edilmesini önermektedir. Araştırma verileri hem YTÖ hem de YİÖ'de bu çalışmaları desteklese de YTÖ'nün bu anlamda daha fazla ders sayısına sahip olması dikkat çekicidir. Çünkü bu konuyla ilgili YïÖ'de sayısız akademik kaynak bulunmaktadır. Akademik kaynakları çok fazla olmasına rağmen ders olarak daha sınırlı kalması tartışmaya açık bir sonuçtur. Öte yandan dil öğretiminde özellikle iletişimsel yaklaşımın benimsendiği günümüzde YTÖ’de 2 dersin, YIÖ’de ise 4 dersin bulunması ciddi bir eksiklik olarak yorumlanabilir.

Psikoloji ve diğer temalarındaki alt temalarla ilişkilendirilen derslerin ortaklık/benzerlik gösterdiği söylenemez. Psikoloji alt temasında dil öğrenme psikolojisi ve motivasyonla ilişkili dersler bulunurken, diğer temasında edebiyat-drama, okuryazarlık, eğitim felsefesi dersleri bulunmaktadır. Bu temalardaki derslerin yaygınlaşması için daha standart bir çerçevede sunulması hem YTÖ hem YïÖ yüksek lisans programları için etkili olabilir. Özellikle dili psikolojik yönden irdeleyen ders sayıları artırılmalıdır. Çünkü dil psikolojisi alanılla desteklenen eğitim öğretim süreci, dil öğrenme sürecindeki sorunların da ortadan kaldırılmasında etkili olabilir (Özbay ve Barutçu, 2013).

Kapsamlı kuramsallaştırma ve etkili uygulamalar için lisansüstü programlar, akademik kültürün sınırlarını belirginleştirmede başat bir rol üstlenmektedir. Yüksek lisans programlarının kuram ve uygulama arasında anlamlı bağlantılar oluşturmaları, üniversitelerin ise özellikle kalite ve akreditasyon çalışmalarının bir parçası olarak program geliştirme/değerlendirme çalışmaları yapmaları gerekmektedir. Bu araştırma kapsamında ele alınan YTÖ ve YïÖ yüksek lisans programlarınının içeriklerini (derslerin) arasında benzerlikler olmakla birlikte önemli ölçüde farklılıklar olduğu görülmüştür. Bu farklılıklar, program içeriklerini ve hedeflerini yeniden düşünmeyi, bazı değişikliklere gitmeyi, tematik değerlendirmelerin daha ince ayrıntılarıyla ele alınmasının gerekliliğini de ortaya koymaktadır. Dolayısıyla bu araştırmanın sonuçları hâlihazırda YTÖ yüksek lisans programı uygulayan ve yeni uygulamaya başlayacak olan üniversitelere, bu programlarda görevli öğretim elemanlarına ve araştırmacılara yol gösterici olabilir. Ayrıca yabancılara Türkçe öğretimi disiplini için bilimsel ve kurumsal kimlik oluşturma sürecinde yol gösretici olabilir. Kumaravadivelu (2012) küreselleşen dünyada stratejik düşünürler, keşif araştırmacıları ve dönüştürücü entelektüellerin yetiştirilmesi için dil eğitiminde kökten bir yeniden yapılanma önermektedir. Henüz gelişme sürecinde olan yabancılara Türkçe öğretimi disiplini için bu kökten yapılanma firsatı değerlendirilmelidir.

RumeliDE Dil ve Edebiyat Araştırmaları Dergisi Osmanağa Mahallesi, Mürver Ciçeği Sokak, No:14/8 Kadıköy - ISTANBUL / TÜRKIYE 34714 e-posta: editor@rumelide.com tel: +90 $5057958124,+902167730616$
Address

RumeliDE Journal of Language and Literature Studies

Osmanağa Mahallesi, Mürver Çiçeği Sokak, No:14/8

Kadıköy - ISTANBUL / TURKEY 34714

e-mail: editor@rumelide.com,

phone: +90 $5057958124,+902167730616$ 
Bu araştırmanın sonuçları temel alınarak aşağıdaki önerilerde bulunulabilir:

YTÖ yüksek lisans programları geliştirme, uygulama ve değerlendirme çalışmaları yapan uzmanlara yönelik öneriler

- Köklü bir geçmişe ve standartlara sahip olan yabancılara İngilizce öğretimi yüksek lisans programlarıyla karşılaştırmalı olarak yapılan bu araştırmanın sonuçları, YTÖ yüksek lisans programı geliştirme, uygulama ve değerlendirme çalışmaları yapılırken dikkate alınabilir.

- YTÖ yüksek lisans programlarında seçmeli dersler, programın disiplinlerarası olma özelliği de göz önünde bulundurularak belirlenmeli ve öğretim programları geliştirilmelidir.

- YTÖ yüksek lisans programlarında kuram teması altında incelenen özellikle dil bilimi ve dil edinimi alt temalarına uygun seçmeli/zorunlu derslerin sayısı artırılmalıdır.

- YTÖ yüksek lisans programlarında pedagoji teması altında incelenen özellikle öğretim yöntem ve teknikleri alt temasina uygun zorunlu derslerin sayısı artırılmalıdır.

- YTÖ yüksek lisans programlarında pedagoji teması altında ölçme-değerlendirme ve program geliştirme alt temalarına uygun seçmeli/zorunlu derslerin sayısı artırılmalıdır.

Araştırmacılara yönelik öneriler

- Bu araştırmada, Türkiye ve İngiltere'de yer alan onar üniversitenin YTÖ ve YiÖ yüksek lisans programları incelenmiştir. Farklı ülkelerden daha fazla sayıda üniversite araştırmaya dahil edilerek çalışmalar yapılabilir.

- $\mathrm{Bu}$ araştırmada yüksek lisans programları incelenmiştir, doktora programlarının da incelendiği araştırmalar yapılabilir.

- $\mathrm{Bu}$ araştırmada, doküman incelemesi yöntemiyle ulaşlan veriler incelenmiştir. Bu programlara devam eden öğrenciler ve program sorumlulularl/ders veren öğretim elemanlarının görüşlerinin değerlendirildiği nicel/nitel araştırmalar yapılabilir.

\section{Kaynakça}

Aslan, C. (2010). Türkçe eğitimi programlarında lisansüstü öğreinim gören öğrencilerin akademik özyeterliklerine ilişkin görüşleri. Mehmet Akif Ersoy Üniversitesi Eğitim Fakültesi Dergisi, 1O(19), 87-115.

Aslan, C. ve Karagül, S. (2016). Türkçe eğitimi programında lisansüstü öğrenim gören öğrencilerin bilimsel araştırma yapmaya yönelik kaygı düzeyleri. Mehmet Akif Ersoy Üniversitesi Eğitim Fakültesi Dergisi, (38), 201-217.

Aytan, T., Uzun, O., ve Günaydın, Y. (2020). Hayat boyu öğrenme yabancılara Türkçe öğretim kurs programlarının çeşitli değişkenler açısından değerlendirilmesi. RumeliDE Dil ve Edebiyat Araştırmaları Dergisi, (21), 70-99.

Balcı, M. ve Melanlığlu, D. (2020). “Türkçenin yabancı dil olarak öğretimi programı" üzerine. Kirlkkkale Üniversitesi Sosyal Bilimler Dergisi, 10(2), 173-198.

Bhabha, H. K. (1988). The commitment to theory. New Formations, (5), 5-23.

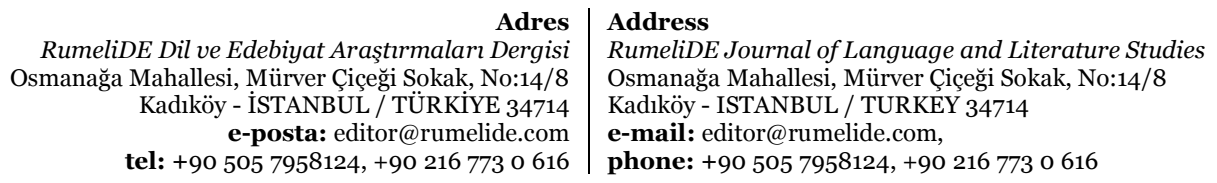


A comparative analysis of master's degree programs on teaching Turkish and English to speakers of other languages / G. Aydın; E.İlhan (pp. 65-86)

Büyükaslan, A. (2007). Yabancı dil Türkçenin öğretilmesinde yeni yöntemler: Bilişim uygulamaları, çözüm önerileri. I. Uluslararası Bilgisayar ve Öğretim Teknolojileri Sempozyumu, 16-18 Mayıs 2007, Çanakkale Onsekiz Mart Üniversitesi Eğitim Fakültesi.

(http://www.turkofoni.org/yabancilara-turkce/ali_buyukaslan._yabanci_dil_turkce.pdf (Erişim Tarihi: 27.03.2021)

Candaş-Karababa, Z. C. (2009). Yabancı dil olarak Türkçenin öğretimi ve karşılaşılan sorunlar. Ankara Üniversitesi Eğitim Bilimleri Fakültesi Dergisi, 42(2), 265-277.

Çetin, O. (2020). Yabancılara Türkçe öğretimi sertifika programlarında görülen eksiklikler ve çözüm önerileri. XV. Uluslararası Büyük Türk Dili Kurultayı Bildiri Kitabı, (s. 366-375), GürcistanTiflis.

Cortazzi, M., \& Jin, L. (1999). Cultural mirrors: Materials and methods in the EFL classroom. In E. Hinkel (Ed.), Culture in second language teaching and learning (pp. 196220). Cambridge: Cambridge University.

Daştan, A., Bayraktar, Y. ve Bellikli, U. (2019). Türkiye'de sosyal bilimler alanında bilimsel araştırma ve yayın etiği eğitimi: İdeali arayış bağlamında bir araştırma. Küresel İktisat ve İşletme Çalş̧maları Dergisi, 8(15), 21-39.

Demiral, S, ve Kökçü, Y. (2018). Yabancılara Türkçe öğretimi sertifika programına katılan öğrencilerin sertifika programları hakkındaki görüşleri. Uluslararası Türkçe Edebiyat Kültür Eğitim (TEKE) Dergisi, 7(3), 1884-1901

Demirbolat-Ottekin, A. (2005). Yüksek lisans öğrencilerinin program ve öğretim elemanlarından beklentileri. Türk Ĕ̆itim Bilimleri Dergisi, 3(1), 47-64.

Durmuş, M. (2013). Yabancllara Türkçe öğretimi. Ankara: Grafiker.

Fraenkel, J. R., Wallen, N. E., \& Hyun, H. H. (1993). How to design and evaluate research in education. New York, NY: McGraw-Hill.

Güzel, A. (2010). Türkçe eğitimi bölümlerinde kurulması gerekli görülen ana bilim dalları. Türklük Bilimi Araştırmaları, 27(Türkçe Öğretimi Özel Sayısı), 371-383

Hasrati, M. \& Tavakoli, P. (2015). Globalisation and MA-TESOL programmes in the UK. High Educ, $69,547-565$.

Hedges, M., Pacheco, G. A., \& Webber, D. J. (2014). What determines students' choices of elective modules? Economics working paper series, 1307. Bristol: University of the West of England.

Ilieva, R. \& Ravindran, A. (2018). Agency in the making: Experiences of international graduates of a TESOL program. System, 79, 7-18.

Ilieva, R., Li, A., \& Li, W. (2015). Negotiating TESOL programs and EFL teaching contexts in China: Identities and practices of international graduates of a TESOL program. Comparative and International Education, 44(2).Article 3, https://ojs.lib.uwo.ca/index.php/cieeci/article/view/9274/7460 sayfasından 14.02.2021 tarihinde erişilmiştir.

İşcan, A. (2014). Yabancı dil öğretimi ve yabancı dil olarak Türkçe öğretiminin tarihçesi. A. Şahin (Ed.), Yabancı dil olarak Türkçe öğretimi içinde (s. 3-32). Ankara: Pegem Akademi.

Karasar, N. (2016). Bilimsel araştırma yöntemi: Kavramlar, ilkeler, teknikler (31. baskı). Ankara: Nobel.

Katerinov, K. (1984). Rassegna dei principali metodi per l'nsagnamento delle lingue straniera. Perugia: Guerra

Kovacs, G. (2017). Culture in language teaching: A course design for teacher trainees. Acta Univ. Sapientiae, Philologica, 9(3), 73-86.

Kramsch, C. (1993). Context and culture in language teaching. Oxford: Oxford University.

Kumaravadivelu, B. (2012). Language teacher education for a global society: A modular model for knowing, analyzing, recognizing, doing, and seeing. New York, NY: Routledge.

\begin{tabular}{r|l} 
Adres & Address \\
RumeliDE Dil ve Edebiyat Araşttrmaları Dergisi & RumeliDE Journal of Language and Literature Studies \\
Osmanağa Mahallesi, Mürver Çiçeği Sokak, No:14/8 & Osmanağa Mahallesi, Mürver Çiçeği Sokak, No:14/8 \\
Kadıköy - İSTANBUL / TÜRKIYY 34714 & Kadıköy - ISTANBUL / TURKEY 34714 \\
e-posta: editor@rumelide.com & e-mail: editor@rumelide.com, \\
phone: +90 505 7958124, +90 2167730616
\end{tabular}


Kurt, B. (2020), Yabancı dil olarak Türkçe öğretimi programına ilişkin kursiyer görüşlerinin karşlaştırılmalı bir analizi. Akdeniz Üniversitesi Ĕ̆itim Fakültesi Dergisi, 3(1), 73-90.

Li, X, Q. (2014). The development and prospects of the international education of Chinese language: Commemorating the $10^{\text {th }}$ anniversary of the establishment of the Confucius Institute. Journal of South Chine Normal University, 5, 120-129.

Lin, L. L. (2010). Examining the effectiveness of TESOL master's programs to prepare graduate students for their current and future careers. https://files.eric.ed.gov/fulltext/ED510734.pdf sayfasından 02.01.2021 tarihinde erişilmiştir.

Liu, Y. M., \& Pan, J.Y. (2018). Research on the selection and training model of chinese teacher volunteers. Overseas Chinese Education, 98(3), 82-87.

Mancester University (2021). MA TESOL. https://www.manchester.ac.uk/study/masters/courses/list/o1367/ma-tesol/coursedetails/\#course-profile sayfasından sayfasından 20.03.2021 tarihinde erişilmiştir.

Merriam, S. B. (2013). Nitel araştırma desen ve uygulama için bir rehber (Çev. S. Turan). Ankara: Nobel.

Miles, B. M. \& Huberman, A. M. (1994). Qualitative data analysis: An expanded sourcebook (Second Edition). London: Sage.

Murphy, J. M. (1997). Phonology courses offered by MATESOL programs in the U.S. TESOL Quarterly, 31(4), 741-764.

O'Leary, Z. (2013). The essential guide to doing your research project. London: Sage.

Özbay, M. ve Bahar, M. A. (2016). Türkenin yabancı dil olarak öğretiminde uzmanlık sorunu. Aydın Tömer Dergisi, 1(1), 1-29.

Özbay, M. ve Barutçu, T. (2013). Dil psikolojisi ve Türkçe öğretimi. Adıyaman Üniversitesi Sosyal Bilimler Enstitüsü Dergisi, 6(11-Türkçenin Eğitimi Öğretimi Özel Sayısı), 933-973.

Di Pietro, R. J., Lantolf, J. P. \& Labarca, A. (1983). The graduate foreign language curriculum. The Modern Language Journal, 67(4), 365-373.

Ramanathan, V., Davies, C. E. \& Schleppegrell, M. J. (2012). A naturalistic inquiry into the cultures of two divergent MA-TESOL programs: Implications for TESOL. TESOL Quarterly, 35(2), 279305 .

Toprak, M. ve Erdoğan, A. (2013). Lisansüstü eğitimde Avrupa yaklaşımı. İ. Güleç, Ö.E. Akgün ve M. Bayrakçı (Ed.), VI. Uluslararası Lisansüstü Ĕ̆itim Sempozyumu Bildiriler Kitabı içinde (s.1036). Sakarya: Sakarya Üniversitesi.

Tuzcu, G. (2003). Lisansüstü öğretim için yurtdışına öğrenci göndermenin planlanması. Milli Eğitim Dergisi, (160), 155-165.

Uçgun, D. (2013). "Yabancı dil olarak Türkçe eğitimi ana bilim dalı"nın gerekliliği üzerine bir değerlendirme. Turkish Studies, 8(9), 2483-2498.

Vasquez, C. \& Sharpless, D. (2009). The role of pragmatics in the master's TESOL curriculum: Findings from a nationwide survey. TESOL Quarterly, 43(1), 5-28.

Wu, Y., Qiu, Y., Hutagalung, F. D., \& McNeill-Keay, C. (2020). A comparison study of curriculum between TESOL in the United Kingdom and TCSOL in China. Journal of Language Teaching and Research, 11(4), 568-581.

Yağmur, K. (2009). Batı Avrupa'da anadili Türkçe olan öğrencilere Türkçenin ikinci dil olarak öğretimi ve kuramsal sorunlar. D. Yaylı ve Y. Bayyurt (Ed.), Yabancllara Türkçe öğretimi politika yöntem ve beceriler içinde (ss. 221-230). Ankara: Anı.

Yıldırım, A. ve Şimşek, H. (2013). Sosyal bilimlerde nitel araştırma yöntemleri. Ankara: Seçkin.

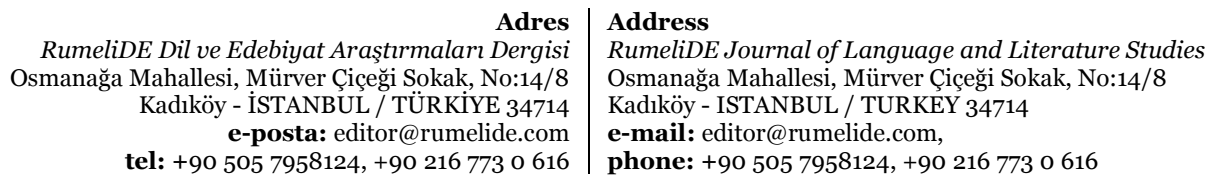


A comparative analysis of master's degree programs on teaching Turkish and English to speakers of other languages / G. Aydın; E.̇̇lhan (pp. 65-86)

YÖK Atlas (2021). Türkçe öğretmenliği programı bulunan tüm üniversiteler, https://yokatlas.yok.gov.tr/lisans-bolum.php?b=10215 sayfasından 18.03.2021 tarihinde erişilmiştir.

York University. (2021). MA teaching English to speakers of other languages. https://www.york.ac.uk/study/postgraduate-taught/courses/ma-tesol/ sayfasindan 20.03.2021 tarihinde erişilmiştir. 